\title{
Soil Indicators of Hillslope Hydrology
}

\author{
Johan van Tol, Pieter Le Roux and Malcolm Hensley \\ Department Soil, Crop and Climate Sciences, University of the Free State \\ South Africa
}

\section{Introduction}

The demand for water doubles every 20 years which is more than twice the rate of the world's population growth. New water resources are becoming scarcer and to treat and remediate existing sources more expensive (Clothier et al., 2008). The protection and management of surface and groundwater resources, especially in the highly variable water regime of semi-arid areas, requires accurate analysis of hydrological processes. This involves the identification, definition and quantification of the pathways, connectivities, thresholds and residence times of components of flow making up stream discharge. It is essential that these aspects be efficiently captured in hydrological models for accurate water resource predictions, estimating the hydrologic sensitivity of the land for cultivation, contamination and development, and for quantifying low flow mechanisms (Lorentz et al., 2007; Uhlenbrook et al., 2005; Wenninger et al., 2008). Ideally these hydrological models can best be developed using measurements of the surface and subsurface lateral flow paths, water table fluctuations, connectivity of the various water bodies and the residence flow time of water through the landscape. The landscape unit that is of particular importance is the hillslope (Karvonen et al., 1999; Lin et al., 2006; Ticehurst et al., 2007), hence the accent here on this landscape unit. The measurements named are however expensive and time consuming since these processes are dynamic in nature with strong temporal and spatial variation (McDonnell et al., 2007; Park \& Van de Giesen, 2004; Ticehurst et al., 2007).

The need for predictions of the named hydrological processes is becoming increasingly important and led to the launch an International Association of Hydrological Sciences (IAHS) initiative called Predictions in Ungauged Basins or PUB (Sivapalan 2003; Sivapalan et al., 2003) encouraging researchers and modellers to focus their efforts on predicting the hydrological behaviour of catchments based on physical principles without relying on calibrations of hydrological models.

Soils integrate the influences of parent material, topography, vegetation/land use, and climate and can therefore act as a first order control on the partitioning of hydrological flow paths, residence time distributions and water storage (Park et al., 2001; Soulsby et al. 2008). The influence of soil on hydrological processes is due to the ability of soil to transmit, store and react with water (Park et al., 2001). Hydrologists agree that the spatial variation of soil properties significantly influences hydrological processes but that hydrologists lack the skill to gather and interpret soil information (Lilly et al., 1998). The relationship between soil and hydrology is interactive. Water is a primary agent in soil genesis, resulting in the formation of soil properties containing unique signatures of the way they formed. Almost every hydrological process of interest to hydrologists is difficult to observe and measure 
(Sivapalan 2003a). Soil properties are not dynamic in nature in the short term, and their spatial variation is not random (Webster, 2000). The correct interpretation of spatially varying soil properties associated with the interactive relationship between soil and hydrology can serve as an indicator of the dominant hydrological processes (Ticehurst et al., 2007; Van Tol et al, 2010a), and improve the understanding of hydrological behaviour of different hillslopes (Lin et al., 2006). The hillslope scale is considered ideal as it is the smallest unit on which most hydrological processes can be observed. The improved understanding can facilitate the development of conceptual, qualitative 2-dimensional descriptions of hillslope hydrological behaviour. These descriptions reflect the physical processes and should be used in the configuration and structure of hydrological models in order to mimic the hydrological behaviour of hillslopes and thereby aid in PUB.

\section{Hydropedology}

The science of hydrology has been poorly serviced by soil science in the past. Soil science started as a natural science in the late $19^{\text {th }}$ century but changed to an applied science in agriculture in the $20^{\text {th }}$ century. This was mainly due to the quest for food security, heightened by the 1st, 2nd world wars and the 'cold' war which followed. During the postwar years attitudes changed internationally as fears about food shortages decreased while apprehension regarding environmental sustainability grew. Agriculture occupies more than $90 \%$ of the land surface in most countries and accounts for around $70 \%$ of fresh water utilization in many developed countries. Rapidly expanding industrialization, increased urbanization, intensified agricultural production and population growth have all contributed during the last six decades towards drastically increasing the environmental pollution hazard. A large fraction of this pollution ends up in the soil, making it a vital role player in pollution control and rehabilitation, thereby broadening its contribution to holistic environmental studies.

The term hydropedology was introduced in 1966 by Kutilek (Kutilek \& Nielson, 2007), and can be defined as the "...synergistic integration of pedology with hydrology to enhance the holistic study of soil-water interactions and landscape-soil-hydrology relationships across space and time, aiming to understand pedologic controls on hydrologic processes and properties, and hydrologic impacts on soil formation, variability, and functions" (Lin et al., 2008). This field aims to bridge gaps between pedology, soil physics, hydrology and geomorphology and also between micro and macroscopic scales of water interactions. Issues covered by hydropedology include: i) hydrology as factor of soil formation, ii) soil as essential component of hydrological cycle and filter of water, iii) soil morphology as signatures of soil hydrology and iv) landscape-soil-water relationships across scales. For excellent reviews and comprehensive discussions on hydropedology see Lin (2003), Kutilek et al. (2007), Van Huyssteen (2008) and Lin (2010).

\subsection{Hydrological flowpaths}

Three major flow pathways exist in a typical hillslope: overland flow, subsurface lateral flow and bedrock flow (Karvonen et al. 1999; Ticehurst et al., 2007). Subsurface lateral flow can be divided into: subsurface macropore flow, subsurface lateral flow at A-B horizon interface, return flow at the footslope and toeslope and flow at the soil-bedrock interface (Lin et al., 2006). These flowpaths are not mutually exclusive, and water tends to move between them. Some paths are only connected when the hillslope is wet. The relative importance of the 
various pathways is determined by soil characteristics, the macropore network and the parent material at the base of the soil (Mosley, 1982). Hydrologic conditioning is influenced by soil depth, pore size and organic matter distribution, tortuosity and the surface and subsurface topography (Sidle et al., 2001).

The role of topography varies with the moisture content of the soil. In drier periods the main controlling factor of movement is soil characteristics. In wetter periods, the topography becomes increasingly important (Lin et al., 2006; McGlynn et al., 2002; Park \& van de Giesen, 2004).

\subsubsection{Overland flow}

Overland flow occurs either as infiltration excess or as saturation excess. In general steeper slopes generate large volumes of overland flow with significant erosive energy. Thinner A horizons usually indicate that the overland flow is dominant, in thicker soils more infiltration due to the greater volume of water needed to saturate the soil is expected. The assumption can be made that thicker soils support more vegetation and this causes a decrease in the overland flow proportion (Ticehurst el al., 2007).

Breaks in slope (normally between midslopes and valley bottoms) reduce the velocity of water and enhance infiltration. The soils in this region are generally thicker, due to deposition of alluvial material and organic matter, which further enhance infiltration. In valley bottoms the runoff rate tends to slow down because of the smaller gradient. These soils are however the wettest in typical hillslopes and the saturated conditions reduce the infiltration rate promoting overland flow.

Where overland flow occurs the water may downslope encounter an area where the soil water deficit has not yet been satisfied, the water then infiltrates. This is called the run-on pathway and is often ignored in rainfall and runoff studies. The water available for infiltration then includes the precipitation as well as water supplied from the upperslope (Nahar et al., 2004).

The amount of overland flow is greatly affected by the texture of the soil, specifically the percentage clay and sand. Sandy soil is generally more permeable and has a greater hydraulic conductivity than clay rich soil, and therefore infiltration excess induced overland flow seldom occurs in sandy soils. In a study by Karnoven et al. (1999) the conductivity of sandy loam soils was 15 times higher than clayey soils.

\subsubsection{Subsurface lateral flow}

Macropores conduct a considerable amount of water during large storms in forested catchments. Water moves through tree root channels, pores created by organisms (earthworms), as well as cracks. Cracks are usually present in soils with a high 2:1 clay content (vertic soils), especially in drier periods (Lin et al., 2006). There are three factors determining the contribution of subsurface macropore flow of water namely; size of the macropores, the accessibility and continuity of the pores. The continuity of these pores seems to increase with an increase in soil moisture (Nieber et al., 2000). Soil pipes are usually flow pathways parallel with the slope and are formed by soil fauna (moles \& mice) as well as dead root channels. They contribute a significant amount of subsurface water to streamflow and are usually quick to respond to rainfall. Pipe flow has a smaller influence in hillslopes with high drainable porosity because water table response is lower due to the high storage potential of the profile (Uchida et al., 2006). 
Lateral flow occurs at A/B horizon interfaces due to differences in the structures, densities and hydraulic conductivities of the horizons. Vertical flow will be hindered and water will tend to move laterally if the A horizon is more permeable than the B horizon. In a study by Lin et al. (2006), the lowest water content was recorded below the interface between the A and B horizons due to the great amount of lateral flow. The lower gradient of lower slope terrain units would limit this lateral flow and promote water logging, as well as overland flow due to excess saturation (return flow). Similar mechanisms might result in a flowpath at the bottom of the profile at the interface between the soil and the underlying parent material. Continuous flow after a storm even with little water in the top of the profile suggested that the water moved vertically in the upperslopes and then laterally at or near the soil-bedrock interface in a study by Lin et al, (2006). The permeability, the depth as well as the differentiation between horizons would affect the amount of water moving through this flowpath. Since the clay content of the B horizon in lower slopes usually shows an increase due to luviation, this pathway would generally originate in the upper slopes.

\subsubsection{Bedrock flow}

Ticehurst et al. (2007) found in their study that the soils from the summit area, which were sandy and shallow, provided and important water intake area for water supply to the bedrock flowpath. The general movement of water in this region is vertical and soils are usually well drained. Due to the age of the soils and the small amount of deposition, little differentiation between horizons is generally present and water drains vertically through the $\mathrm{B}$ horizon into the $\mathrm{C}$ horizon. The water that doesn't move on top of the bedrock moves through cracks in the bedrock or on solid bedrock within the saprolite. The bedrock flowpath is extremely important for recharge of lower slopes, groundwater levels and generating baseflow in some catchments (Fanning \& Fanning 1989; Ticehurst et al., 2007).

\subsection{Signatures and control mechanisms}

Soil properties, soil horizons, soil profiles and soil patterns are not randomly distributed (Webster, 2000). These soil features are influenced by five soil forming factors i.e. climate, topography, geology, organisms and time. The combination of these factors results in unique soil properties with distinctive vertical and horizontal distributions. These properties and their distribution not only influence hydrological processes but can also serve as verification on the way they were formed. A few examples are presented.

\subsubsection{Redox morphology}

Soil morphology developed by oxidizing, reducing and redox conditions serves as signatures of flowpaths and storage mechanisms in soils, hillslopes and catchments. Reducing conditions increase down the profile, down slope and with increasing rainfall if all other factors playing a role in the redox process, remains the same. Redox features in soils involve localities where there is depletion in $\mathrm{Fe}^{3+}$ and $\mathrm{Mn}^{2+}$ concentrations and localities where there is accumulation of $\mathrm{Fe}^{3+}$ and $\mathrm{Mn}^{2+}$ (Soil Survey Staff, 1992). Depletion in $\mathrm{Fe}^{3+}$ and $\mathrm{Mn}^{2+}$ is associated with low chroma values (grey colours), and accumulation of $\mathrm{Fe}^{3+}$ and $\mathrm{Mn}^{2+}$ is associated with high chroma colours (yellow, red and black) in the form of mottles and concretions (Le Roux, 1996).

Micro organisms utilize $\mathrm{O}_{2}, \mathrm{NO}_{3}^{-}, \mathrm{Mn}^{2+}, \mathrm{Fe}^{3+}$ and $\mathrm{SO}_{4}^{2-}$ as oxidation agents (electron acceptors) and easily oxidisable organic matter as reduction agent. These reactions occur 
sequentially from most likely to least likely to be reduced. In the oxidized state $\mathrm{Fe}^{3+}$ and $\mathrm{Mn}^{2+}$ are insoluble, and in the reduced state, very soluble. Reduced localities have high $\mathrm{Fe}^{2+}$ and $\mathrm{Mn}^{+}$concentrations in solution. They diffuse to oxidised localities where the concentration in solution is low to be oxidized again (Van Breedeman \& Brinkman, 1976). Grey colours of the silicate clay, quartz and feldspar soil minerals are grey and therefore grey colours appear where the Fe coatings are removed (Vepraskas \& Bouma, 1976). Yellow, red and black colours occur juxtapositioned where $\mathrm{Fe}^{3+}$ and $\mathrm{Mn}^{2+}$ accumulate in sequence with an increase in $\mathrm{Fe}^{3+}$ and $\mathrm{Mn}^{2+}$ concentration (Le Roux, 1996).

Redox features are easily observed in plinthic soils. Plinthic horizons have an accumulation of iron in the form of oxides and hydroxides and are localized in the form of high chroma mottles and concretions. The simple processes leading to the formation of such a horizon are eluviation (removal of constituents), illuviation (accumulation of eluviated material), oxidation and reduction (Fanning \& Fanning, 1989). $\mathrm{Fe}^{3+}$ is reduced and together with sesquioxides eluviated from the upper lying horizons and $\mathrm{Fe}^{2+}$ oxidized and accumulates in the lower horizon. A fluctuating water level is necessary for this to take place.

Plinthite normally occurs in highly weathered soils of the regions with rainfall exceeding $500 \mathrm{~mm}$ and where a fluctuating water table is active. High temperatures and a high evaporative demand favour plinthite formation since they influence the fluctuation of water levels. The formation of plinthite on different topographical positions corresponds to the climate. In the drier climates plinthite forms in the lower lying areas. Redoximorphic features occur in soils of semi-arid climates and wetter. The key factor is a ratio of rainfall/evapotranspiration resulting in water flowing to the deep subsoil and impermeable deep subsoil preventing water loss to the fractured rock and result in subsoil saturation. These conditions typically occur in semi-arid climates and wetter.

The relationship between wetness and position in the landscape is reflected through the variation in soil colour. In a typical catena the red Fe rich soils are typically found on the higher lying drier positions of the hillslope, whereas grey gleyed soils can generally be found in the wetter lower-slope terrain positions. Long term data proves that yellow soils are normally better drained than grey soils, but wetter than red soils (Van Huyssteen \& Ellis, 1997; Van Huyssteen et al., 2005).

\subsubsection{Presence of calcium carbonate $\left(\mathrm{CaCO}_{3}\right)$}

The dependence of calcareous precipitates on the presence and behaviour of water makes it a good indicator of hillslope hydrology. Calcretes are materials formed by cementation or selective replacement of the soil particles by carbonate. Calcareous layers in soils are controlled by the soil water regime and are typically found in arid to sub-humid regions. Lime precipitates in the soil due to limited leaching which can be brought about by two processes: leaching that can be limited due to low rainfall/high evapotranspiration, or restricting subsoil layers and associated saturated conditions (Driessen \& Deckers., 2001; Netterberg, 1978).

In sub-humid to arid regions, calcification is one of the main processes in soils with carbonate rich parent materials. Weathering of the parent material results in the formation of soils with calcium as the major cation on the cation exchange complex. $\mathrm{CaCO}_{3}$, the dominant carbonate in these soils, is pedogenically formed as follows:

$$
\mathrm{Ca}^{2+}+\mathrm{CO}_{2}+\mathrm{H}_{2} \mathrm{O} \rightarrow \mathrm{CaCO}_{3}+\mathrm{H}_{2}
$$


Weathered $\mathrm{Ca}^{2+}$ dissolves in water leaches towards lower soil horizons and flows downslope, and filling voids and pores. Plant roots extract water and precipitation in the form of $\mathrm{CaCO}_{3}$ occurs due to the presence of $\mathrm{CO}_{2}$. The $\mathrm{CO}_{2}$ are present in the soil as a consequence of diffusion from the atmosphere, but $\mathrm{CO}_{2}$ generated by oxidation of plant roots enhance this process, especially when the natural vegetation consists of grasses and shrubs. This process is the first stage of the formation of a calcic horizon (Fanning et al., 1989; Shankar \& Achyuthan, 2007).

According to Netterberg (1978), the presence of calcretes can serve as indicators of previous (fluctuating) ground water levels as well as of preferred flow paths (faults). When the parent material contains small amounts of $\mathrm{CaCO}_{3}$ and the amount of $\mathrm{CaCO}_{3}$ in the profile exceeds the amount that could be released by weathering, the presence of $\mathrm{CaCO}_{3}$ in the soil can be ascribed to the second process namely, deposition of $\mathrm{CaCO}_{3}$ rich dust from coastal shelves (Bockheim \& Douglass, 2006).

\subsubsection{Soil depth and porosity}

Soil depth is the result of the balance between the rate of weathering and the rate of erosion. Under similar climate and hydro-topographical conditions the rate of weathering of the parent material is controlled by the nature of the rock. Porosity (f) is a measure of the total void space in a porous material and is measured, either as a percentage (between 0 and $100 \%$ ), or as a fraction (between 0 and 1 ) of the bulk volume. It is defined by the formula:

$$
f=1-\rho_{d} \div \rho_{s}
$$

Where $\rho_{d}$ is the bulk density $\left(\mathrm{Mg} . \mathrm{m}^{-3}\right)$ and $\rho_{\mathrm{s}}$ is the particle density $\left(\mathrm{Mg} \cdot \mathrm{m}^{-3}\right.$, generally taken as 2.65 in soils low in organic matter). Soil depth together with the porosity determines the storage capacity of the soil.

In a South African case study, the storage capacity of two semi-arid catchments was determined (Van Tol et al, 2010a). The average soil depth of catchment B3 was $450 \mathrm{~mm}$ and that of B4 \& B5 was $190 \mathrm{~mm}$ (due to similarities in B4 and B5 they were considered as one catchment). The average porosity of B3 was $301.5 \mathrm{~mm}$ compared to $130.6 \mathrm{~mm}$ of B4 \& B5. Although the area of B3 is smaller $\left(40.7 \mathrm{~km}^{2}\right)$ than that of B4 \& B5 $\left(49.4 \mathrm{~km}^{2}\right)$, it can store almost twice the volume of water $\left(12.5 \times 10^{6} \mathrm{~m}^{3}\right.$ compared to $\left.6.7 \times 10^{6} \mathrm{~m}^{3}\right)$. This facilitates more water infiltration, greater water holding capacity, a greater volume of water contained at saturation and at drained upper limit. This results in more interflow at the A/B-horizon interface and at the soil/bedrock interface, more water contributing to groundwater bodies and consequently a longer duration of streamflow. More water is available for transpiration resulting in a denser vegetative cover.

The thickness of the soil further influences the residence times of water in catchments. This influence can be more important than that of the slope length, or upslope contribution area (Asano et al., 2002). Shallow soils, with a small storage capacity tend to saturate quickly favouring the generation of overland flow due to saturation excess, resulting in short residence times and high peak flows.

\section{Hydrology of soil types}

"Theory development will advance if we can develop simple models (which may be caricatures of the basin system but, nevertheless, contain within them the basic properties of 
the actual basins), provided, importantly, that they can be verified with large-scale patterns extracted from the observed data" (Sivapalan, 2003). In order to develop simple conceptual hydropedological models (and to improve our understanding of the role of hydropedology in both the natural environment and agriculture), it is necessary to understand key hydrological processes, the impact of soil on these processes and the influence of these processes on soil formation.

This relationship between soil and water is however difficult to comprehend at hillslope or catchment scale. For example; water may drain from the soil into the rock and then return to the soil. It may also exit the soil again as return flow. Where a water table occurs in the soil it is often uncertain whether the soil is feeding the rock aquifer or vice versa. This interaction between soil and hydrology can be simplified by firstly studying this interaction at a pedon scale. In this section soils are divided into different soil types based on their hydrological behaviour, similar to the Hydrology of Soil Types (HOST) classification system. In HOST the soils of the UK were divided into 29 classes based on their hydrological response (Boorman et al., 1995). In this section we only focus on three main response mechanisms of soils and use six years of soil moisture content measurements to support the classification. Because hydropedology is a rather young and complex subject, with relatively few quantitative measurements worldwide to verify hypotheses, we considered it wise to include only local case studies about which we have sufficient knowledge and as much quantitive information as possible.

\subsection{Hydrology of soil types}

It is hypothesized that soils can be grouped in three main hydropedological types based on their hydrological response: recharge soils, interflow soils and responsive soils. Data from the Weatherley research catchment $\left(31^{\circ} 06^{\prime} 6^{\prime \prime S} / 28^{\circ} 20^{\prime} 13^{\prime \prime} \mathrm{E}\right)$ in South Africa (Van Huyssteen et al., 2005) was used to distinguish between these soil types using the degree of water saturation (s), measured over six years. The degree of water saturation is the volume of water relative to the (f) (Hillel, 1980). Porosity can be calculated using equation 2 and the degree of water saturation as:

$$
s=V_{W} \div V_{f}
$$

Where $s$ is the degree of saturation (as fraction), $V_{W}$ is the water content $\left(\mathrm{mm}^{3} \mathrm{~mm}^{-3}\right)$ and $V_{f}$ is the total pore volume $\left(\mathrm{mm}^{3} \mathrm{~mm}^{-3}\right)$. Complete saturation $(\mathrm{s}=1)$ is seldom reached since air is usually trapped in pores by water (Hillel, 1980). The drained upper limit (DUL) i.e. the water content below which drainage due to gravity virtually ceases is expected to be around 0.65 in most soils.

The term "annual duration of degree of water saturation above 0.7 of porosity" $\left(\mathrm{AD}_{\mathrm{s}>0.7)}\right)$ is the first approximated threshold value for the onset of reduction (Van Huyssteen et al., 2005). The degree of saturation before the start of reduction will however differ between areas, soil forms and horizons since numerous factors influence redox conditions in soils. It is because redox reactions of significant extent in soils leave well defined morphological footprints e.g. mottling and/or grey colours, that $\mathrm{AD}_{\mathrm{s}>0.7}$ is considered to be a useful parameter in hydropedological studies. $\mathrm{AD}_{\mathrm{s}>0.7}$ was measured in days per year. The mean annual duration in days of events with $s>0.7\left(D_{s}>0.7\right)$ was calculated as follows (Van Huyssteen et al., 2005):

$$
D_{s>0.7}=A D_{s>0.7} \div F_{s>0.7}
$$


Where $F_{s>0.7}$ is the mean annual frequency of events where $s>0.7$ (events year-1).

Soils were classified according to Soil Classification - A taxonomic system for South Africa (Soil Classification Working Group, 1991) although equivalent classification accordance with WRB (IUSS Working Group WRB, 2006).

\subsubsection{Recharge soils}

Several soils in the Weatherley catchment qualify as recharge soils. The average annual duration of saturation above 0.7 of porosity $\left(\mathrm{AD}_{\mathrm{s}>0.7}\right)$, expressed as a $\%$ of 365 days, is not significant in these soils (Fig. 1) as conditions near saturation only occur when drainable water accumulates. The short degree of saturation in the subsoil shows that water draining through the soil exits the solum to enter the fractured rock underneath.

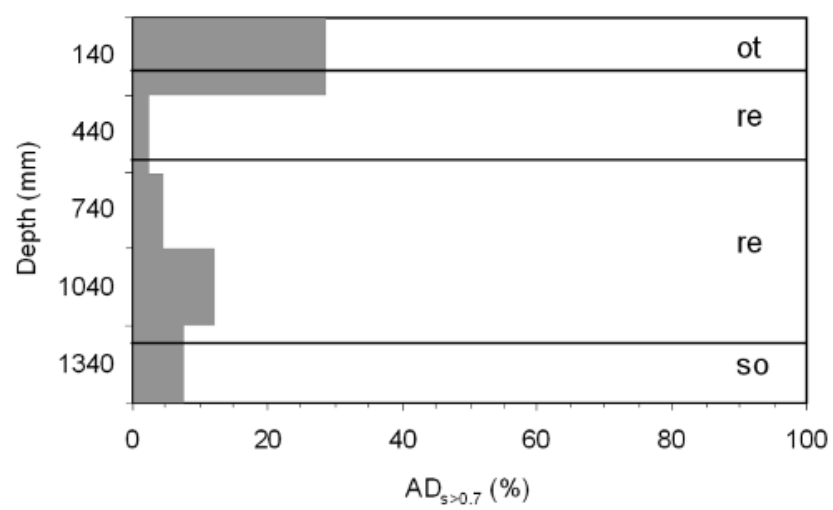

Fig. 1. Mean $\mathrm{AD}_{\mathrm{s}>0.7}$ (\%) values in a typical recharge soil: P221, Hutton 2100 (WRB Orthidistric Cambisol), Weatherley (after Van Huyssteen et al., 2005)

In recharge soils, the hypothesis is that dominant flow direction is vertical. These soils typically occur on the crest or midslope positions on hillslopes with gentle slopes. Precipitation infiltrates the soil and water flows vertically through the pedon under gravitational forces. The underlying permeable bedrock facilitates infiltration of water. From a hydrological perspective the formation and distribution of recharge soils is therefore dependant to a large extent on the permeability of the underlying material. Depending on the nature of the underlying material the infiltrated water can either recharge regional water tables directly, or in the case of aquicludes or aquitards, move laterally after leaving the soil. This lateral moving water can then recharge the stream through transient or perennial groundwater. Its contribution to transient groundwater may be uncertain. Since these flowpaths through the bedrock are usually the longest, recharge soils are important for generating base flow. Recharge soils show no evidence of saturation in any part of the profile. The annual rainfall and potential evapotranspiration should however be considered when classifying a soil as a recharge soil. In arid areas, precipitation is insufficient for redoximorphic features to form and the soils would be classified as recharge soils based on morphological properties even though they are not freely drained.

The contribution of recharge soils to catchment hydrology by implication stops when the soil water balance is negative (i.e. ET $>$ P). This limits its activity to the wet part of the rain 
season (Fig. 2). Three phases are clearly visible in the graph namely a wetting up cycle with the start of the rain season, a wet phase during the rainy season and a drying phase in the waning portion of the rain season. The drying phase is only stopped by the start of the wetting up phase of the following rain season or when the water content is lower than the lower limit of plant available water.

The wetting up cycle depends on the precipitation, atmospheric demand (ET) and the size of the reservoir. As the grass vegetation of the Weatherley catchment mainly extracts its water from the upper $900 \mathrm{~mm}$ (Zere, 2005) of soil, a relative large volume of soil has to be brought to drained upper limit (DUL) before draining starts. In the majority of years (four out of six) this, cycle is two weeks in duration. In the wet cycle the water content of the recharge soils depends mainly on the distribution of rainfall events. Profile water exceeding DUL drains beyond reach of the grass roots.

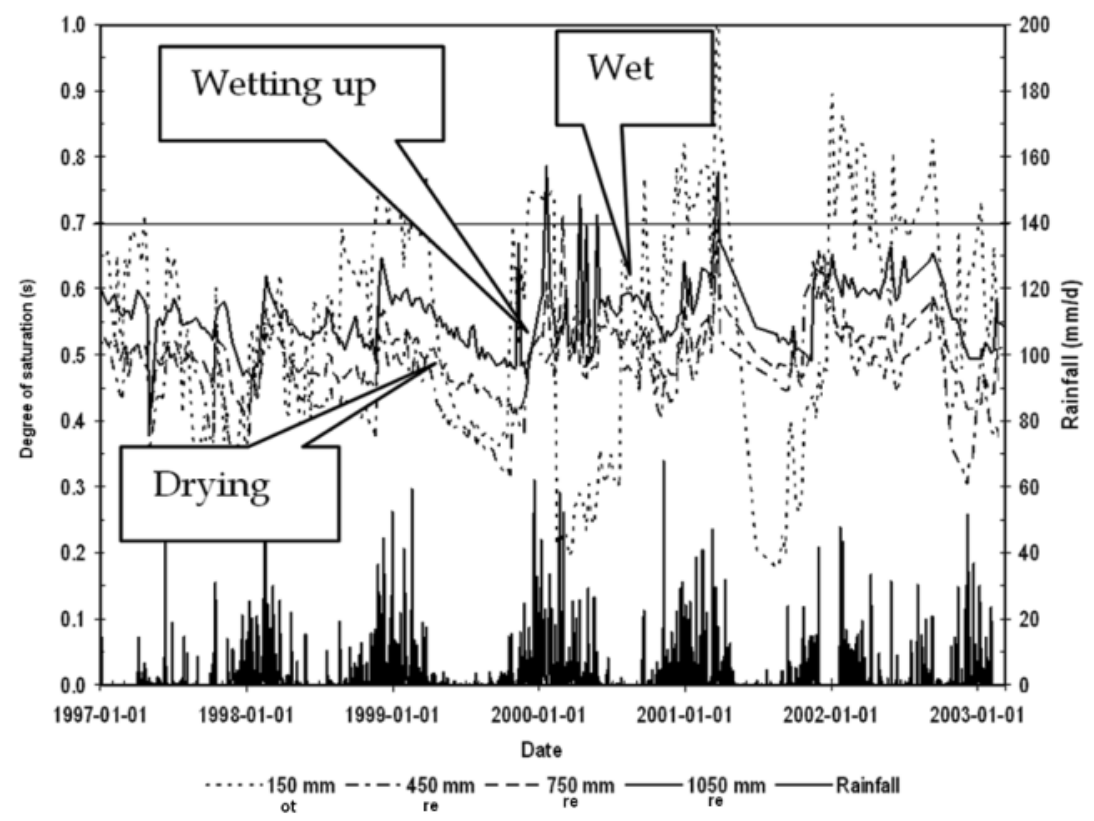

Fig. 2. Degree of saturation vs. rainfall over 6 years of a recharge soil: P221, Hutton 2100 (WRB - Orthidistric Cambisol) in the Weatherley catchment (after Van Huyssteen et al., 2005)

\subsubsection{Interflow soils}

The $\left(\mathrm{AD}_{\mathrm{s}>0.7}\right)$ values in the subsoils of interflow soils is distinctive (Fig. 3). Conditions of water contents near saturation (drainable water) occur in all horizons but typically increase with depth. Interflow soils are associated with subsurface lateral flowpaths. For interflow to occur a layer with lower hydraulic conductivity must be present (B horizon or bedrock with restricted permeability) as well as a slope favouring lateral movement down the slope. Interflow soils are therefore typically found in midslope positions with fairly steep gradients. Water starts moving laterally when infiltrated water encounters a layer with 
lower hydraulic conductivity (A/B horizon interface; soil - bedrock interface or a saturated layer) or when water, fed from upslope recharge soils, encounters such a layer and may return to the soil.

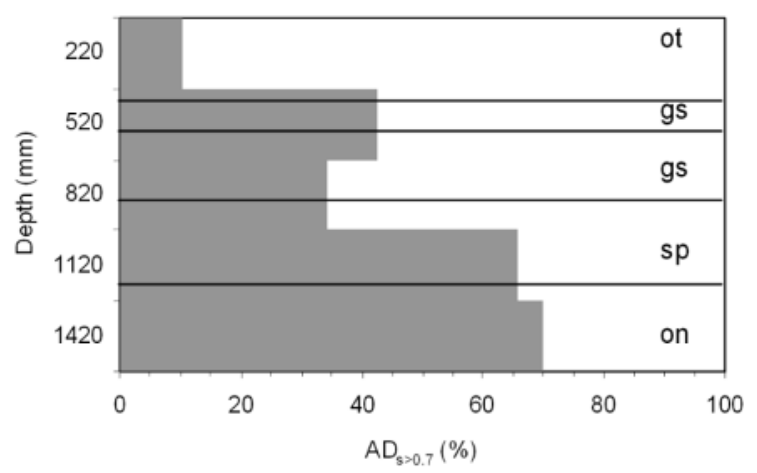

Fig. 3. Mean $\mathrm{AD}_{\mathrm{s}>0.7}(\%)$ values in a typical interflow soil: P225, Longlands 1000 (WRB Ferric-Endoeutric Albeluvisol) in the Weatherley catchment (Van Huyssteen et al., 2005)

Interflow soils have in contrast with the three phases of recharge soils, a distinctive drainage phase, above DUL (Fig. 4). The duration of ADs $>0.7$ in the soft plinthic (sp) horizon of $\pm 67 \%$ i.e. 244 days or 8 months (Fig. 3) is an indication that this soil body generally releases water up to the end of August. This implies a 5 month draining phase i.e. stretching from the end of the rain season (early April) to the end of the dry season in August.

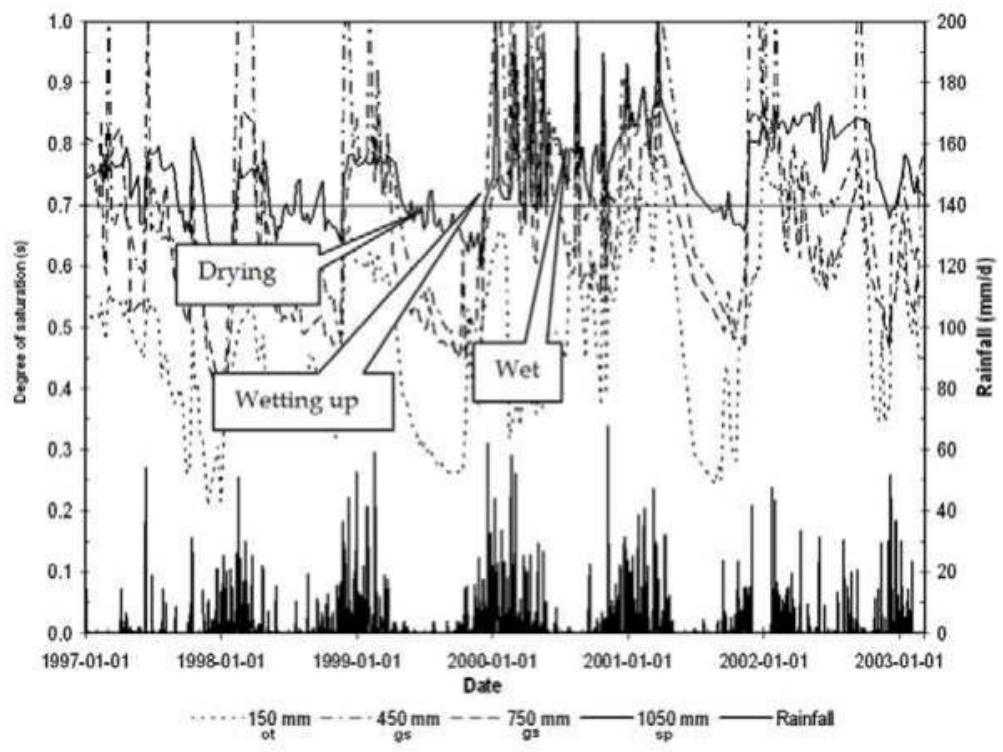

Fig. 4. Degree of saturation vs. rainfall over 6 years of an interflow soil: P225, Longlands 1000 (WRB - Ferric-Endoeutric Albeluvisol) in the Weatherley catchment (after Van Huyssteen et al., 2005) 
During the wet phase losses of water by drainage and ET are sometimes slower than additions of water by precipitation, and interflow results in a rise of the transient groundwater into the plinthic, $\mathrm{E}$ and A horizons. Such a fluctuating water table is typical of subsoils with plinthic and E horizons (Soil Classification Working Group, 1991). These fluctuations are event driven and can be related to rainfall events. The catchment must first fill up before transient groundwater can occur.

Sub soil flowpaths are associated with a residence time shorter than the bedrock flowpaths and longer than overland flow. Interflow soils would therefore contribute mainly to the shoulder of the hydrograph, and to some extent to baseflow. Interflow soils normally have morphological indications of periodic saturation in the profile. If dominant flow exists on the A/B horizon interface, eluvial horizons form. These horizons show marked removal of colloidal material and organic matter. When interflow occurs at the soil/bedrock interface, the transitional horizon usually show indications of periodic saturation.

\subsubsection{Responsive soils}

Responsive soils can either be very shallow soils with low infiltration capacity, saturated soils which prohibit water infiltration or soils prone to form crusts resulting in low infiltration rates and generating Hortonian overland flow. In the Weatherley catchment responsive soils generate overland flow due to saturation excess. The overland flow component contributes to peak flow as the first part of the peak of the hydrograph. The influence of the water content of the topsoil on the generation of overland flow is illustrated in Fig. 5. The results show that overland flow only becomes significant when the topsoils are close to saturation. Overland flow from responsive soils is therefore expected in the wettest positions in landscapes i.e. valley bottoms and wetlands. In the Weatherley catchment these soils are at or near saturation for long periods (Fig. 6), resulting in conditions called saturation excess overland flow in the rain season.

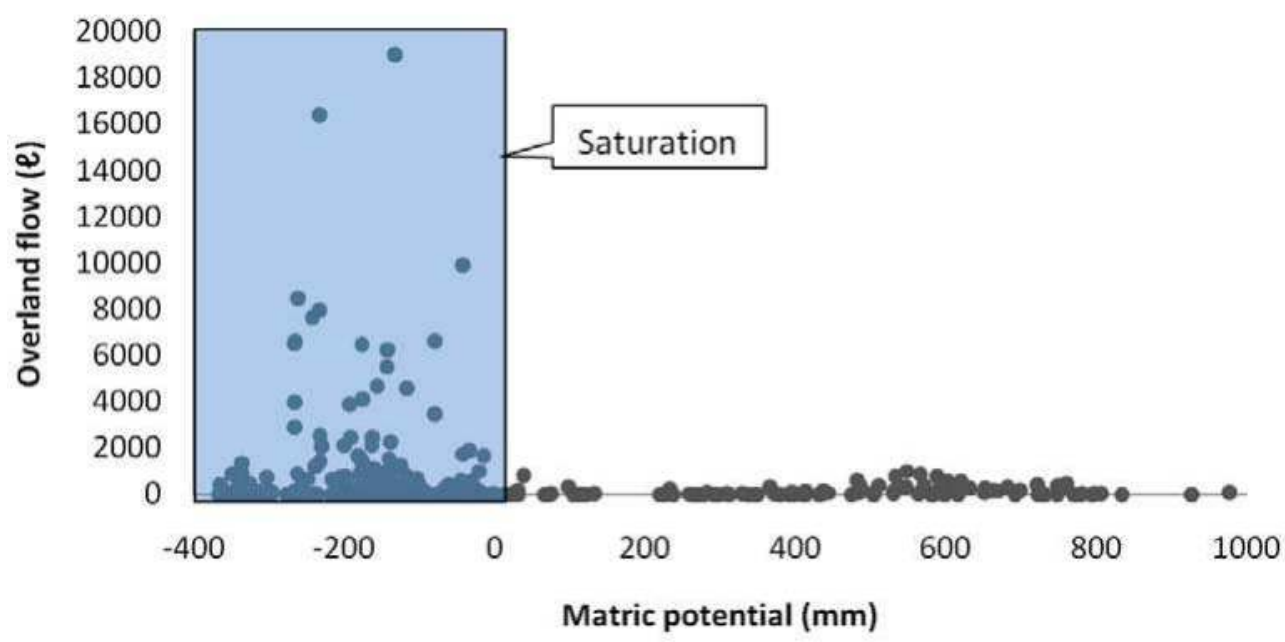

Fig. 5. Volume of overland flow measured at five runoff plots vs. topsoil matric potential in the Weatherley catchment 


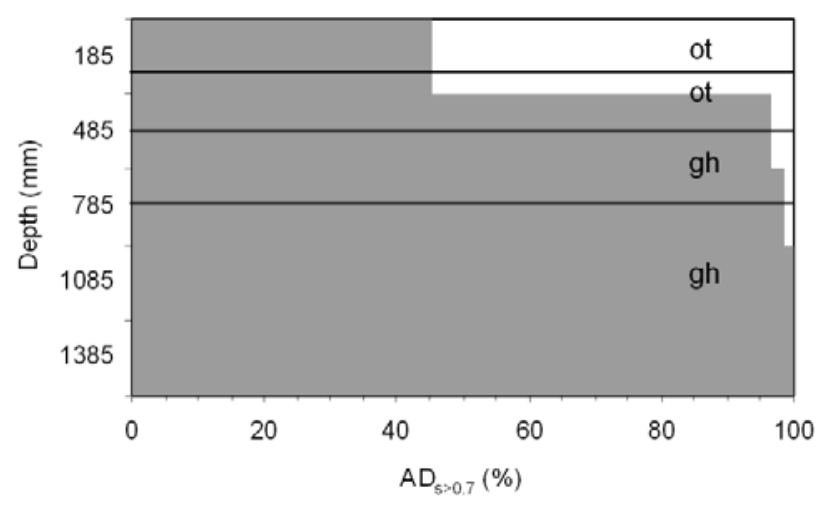

Fig. 6. Mean $\mathrm{AD}_{\mathrm{s}>0.7}(\%)$ values in a typical responsive soil: P235, Katspruit 1000, (WRB Hyperdistric Gleysol) in the Weatherley (Van Huyssteen et al., 2005)

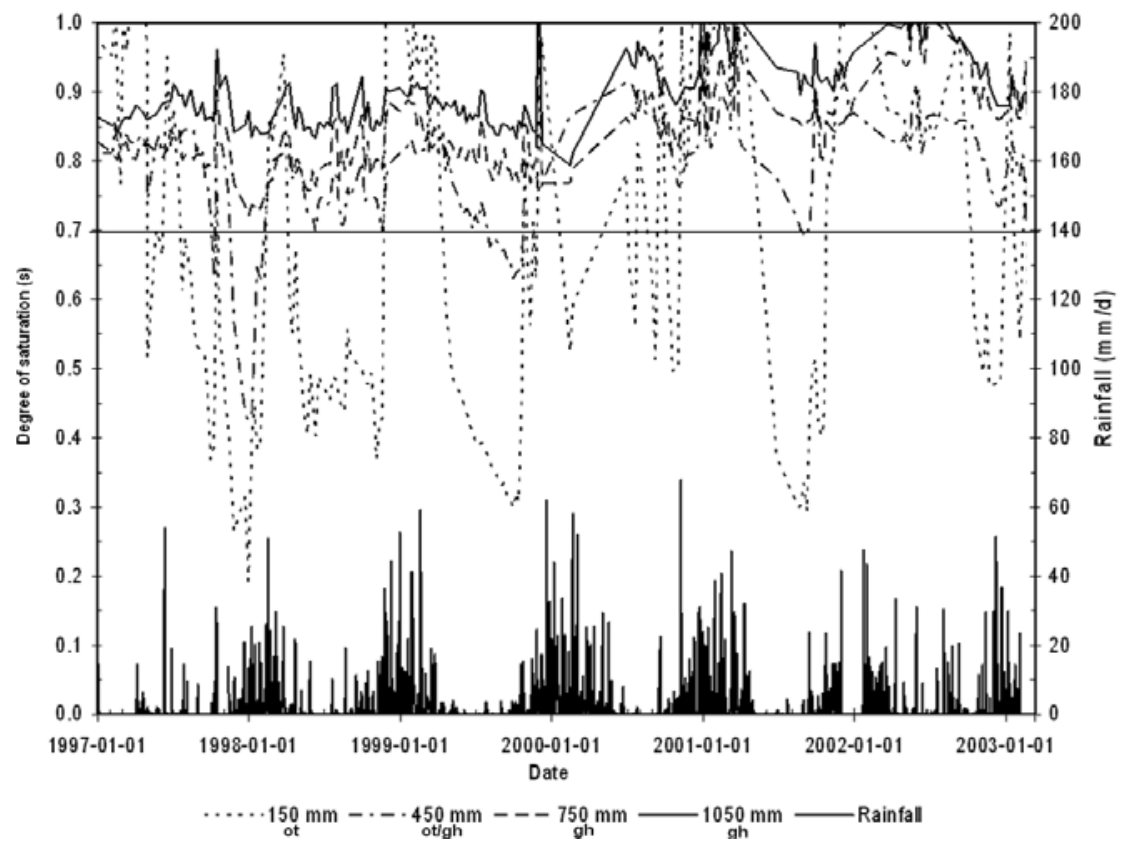

Fig. 7. Degree of saturation vs. rainfall over 6 years of a responsive soil: P235, Katspruit 1000, (WRB - Hyperdistric Gleysol) in the Weatherley catchment (after Van Huyssteen et al., 2005)

Due to long periods of saturation the subsoil ( $g h$ horizon) lacks an obvious wetting and draining phase since it is saturated or close to saturation throughout the year. Only the topsoil horizon loses water to ET during the dry season (Fig. 7). In order for these subsoils to remain saturated for such long periods under incessant ET demand there needs to be a constant supply of water. It is hypothesized that the recharge soils of the upper slopes 
supply water to the responsive soils via the bedrock flowpath and to a lesser extent through interflow.

\section{Conceptual models of hillslope hydrological behaviour}

Deducing the hydrological behaviour of a soil profile without considering its position in the landscape might lead to false interpretations. It is therefore important to obtain a holistic understanding of how hillslopes behave hydrologically. In the case studies reported here soil properties and their spatial distribution (both vertically and horizontally) were interpreted and related to their hydrological response. From these interpretations 2dimensional descriptions of the hydrological behaviour were formulated. Two examples of these conceptual models are presented in this chapter. For detailed discussions on these examples, study area descriptions and more conceptual examples see Le Roux et al. (2010) and van Tol et al. (2010a).

\subsection{Conceptual model of the hydrological behaviour of a hillslope in the Weatherley catchment}

A conceptual description of a hillslope in the Weatherley catchment is presented in Fig. 8 (van Tol et al., 2010). The soil forms and their associated properties along with their spatial distribution were interpreted to develop the conceptual model of the hydrological behaviour of the hillslope.

The dominant processes (flowpaths and storage mechanisms) in Fig. 8 are indicated by numbers plus a letter in box inserts related in each case to arrows of different sizes; these inserts are included in the text enclosed in a bracket. A discussion of these processes follows in what can be considered as a hypothesis, based on hydropedology, of the hillslope hydrology.

When it rains infiltration dominates in the upper regions of this hillslope (1a). Gentle slopes as well as dense vegetation impede overland flow and facilitate infiltration. The absence of any signs of wetness in the soil of the upperslope indicates that vertical drainage through the profile is dominant. The texture is non-luvic and the clay content is therefore relatively uniform with depth. No, or very little, lateral flow is expected to occur at the A/B horizon interface. These are considered to be true recharge soils since no signs of wetness were recorded in soil profile 240 up to a depth of $1500 \mathrm{~mm}$, indicating that water does not perch in the pedon within this depth. Water draining through 240 therefore either infiltrates the subsurface layers (2a) or flows at the soil/bedrock interface (3a). The latter was not reached with auger observations down to $2400 \mathrm{~mm}$.

Any water which does infiltrate the fractured rock would then either flow vertically and recharge regional aquifers $(2 b)$ or, when it encounters a layer with restricted permeability (aquitard), it would flow laterally (3b) and recharge perennial hillslope groundwater downslope.

The presence of interflow soils located where the rock bedding plain surfaces near Uc8 is an indication that the bedding plane (sandstone rock shelf of the Molteno formation) has restricted vertical permeability promoting considerable flow at the soil/bedrock interface (3a). The greater part of the water draining through the soil of the upper slope is therefore expected to flow laterally at this soil/bedrock interface.

Return flow (ex-filtration) to the soil surface (4) is expected as water flowing at the soil/bedrock interface reaches the protruding Molteno shelf. The amount of water exceeds 
the storage capacity of the soil and returns to the surface contributing to overland flow. It is expected that the overland flow has a relatively short duration as the water will re-infiltrate when it reaches the soils below the rock outcrop $(1 \mathrm{~b})$.

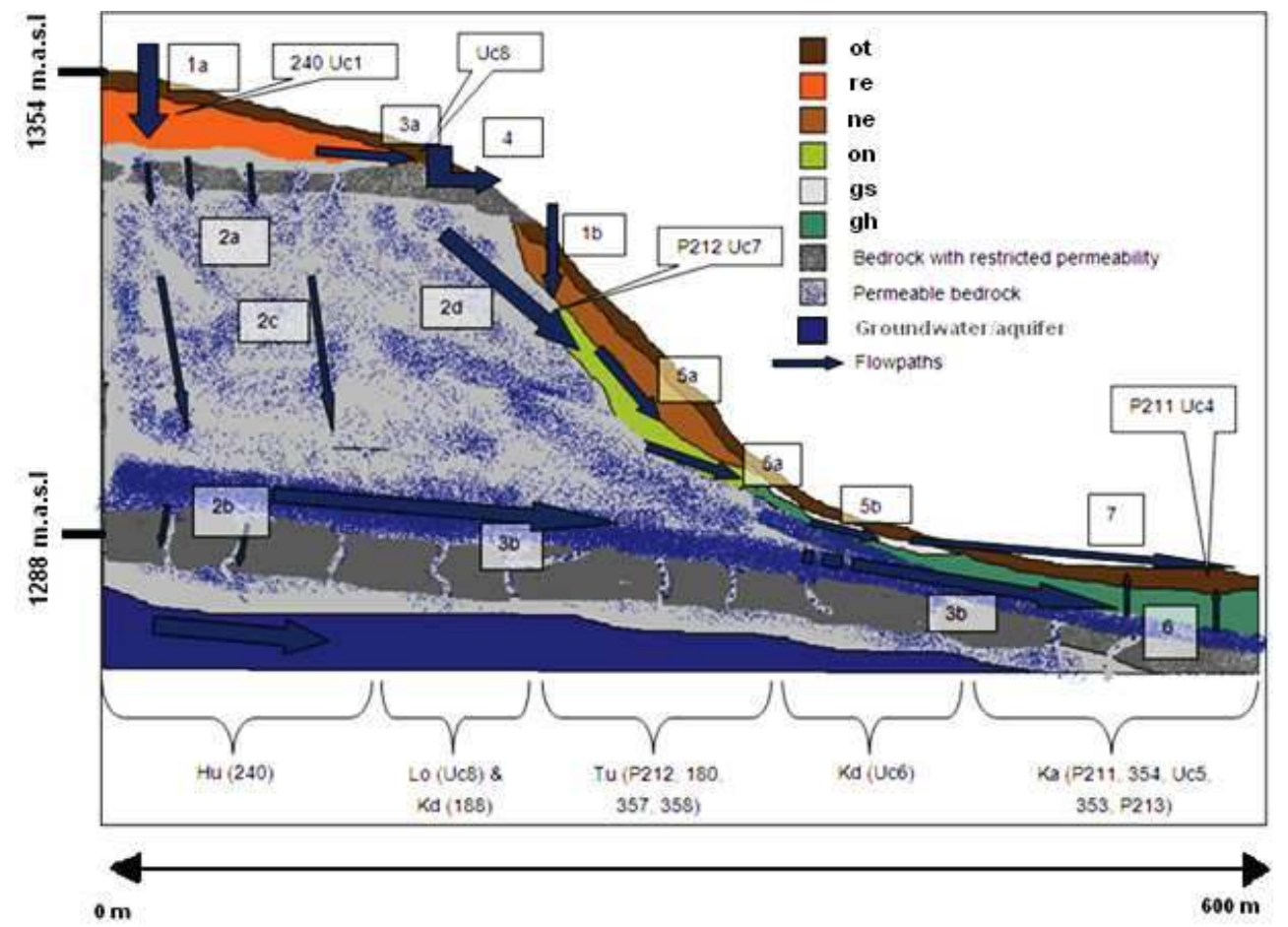

Fig. 8. Conceptual hydrological behaviour of the selected hillslope based on soil interpretations. Various processes are indicated by the numbered arrows

Subsurface lateral flow (5a) in the form of flow at the soil/bedrock interface is indicated by the on horizon (WRB - cambic) present in the deep subsoil of the Tukulu (WRB - (Orthieutric Cambisol) soil of the midslope at P212. This soil body is situated on the Molteno Formation. Groundwater responsible for the redoximorphic features of the on horizon is evidently supplied from the recharge soils as return flow from the bedrock (2d). This return flowpath is expected to result in a fairly constant supply of water during the wet seasons to the on horizon, reflecting its association with perennial groundwater.

The gs horizon (WRB - albic) in the soils of the lower slopes is an indication of the lateral flow of groundwater dominating at the A/B horizon interface (5b). Gleyed soils cover the entire TMU 4 \& 5 positions of this hillslope. The gleyed conditions are indications that these profiles are saturated for long periods. The gh horizons (WRB - gley) have a low hydraulic conductivity that impedes infiltration. Precipitation does not infiltrate into these soils due to the saturated state of the $g h$ horizon. The water maintaining saturation in these lower areas must therefore have another origin. It is believed that there is another layer with restricted 
permeability present in the hillslope (Fig. 8). This layer deflects water which has infiltrated through the recharge soils of the upperslope towards the lower lying areas (3b), resulting in the presence of a perennial aquifer. These very wet soils respond rapidly to precipitation providing overland flow to the stream, the process described as saturation excess overland flow (7). Near surface macropore flow might also play a significant role in this area, as water from the $g h$ horizon pushes up into the more porous ot horizon (WRB - ochric) and then flows laterally. The ot horizons of the soils in the lower slope have Fe and Mn mottling, confirming periodic saturated conditions.

Since the $g h$ horizons in the lower footslope and toeslope positions (Fig. 8) are saturated for long periods, the dominant flow direction within the pedon is upwards (6). Evapotranspiration will presumably extract more water from the soil than can infiltrate.

\subsection{Conceptual model of hillslope hydrological behaviour in the Two Streams catchment}

The conceptual model of the hydrological behaviour of two hillslopes in the Two Streams catchment $\left(29^{\circ} 12^{\prime} 23^{\prime \prime} \mathrm{S} / 30^{\circ} 39^{\prime} 10^{\prime \prime} \mathrm{E}\right)$ is presented in Fig. 9 (Le Roux et al., 2010). The number arrows represent dominant hydrological processes. Note that the slope on the right faces south and that on the left hand side of Fig. 9 faces north. This difference in aspect has resulted in distinct morphological characteristics of the soils in the slopes; north facing slopes in the southern hemisphere are generally drier compared to south facing slopes due to more direct sunlight. The soils on the south facing slope are therefore more reduced and exhibit yellow colours compared to the dominant red colours on the north facing slope.

The dominant process in this catchment is infiltration and vertical drainage of precipitation (1 in Fig. 9). The soils in the upper slopes are considered freely drained with no indications of periodic saturation in the A and B horizons. These soils are considered to be recharge soils. Water exits the solum and drains into the highly weathered saprolite (so).

Vertical drainage remains dominant until more impermeable rock is reached, where the flow is deflected in a lateral direction (2). This lateral moving component feeds the stream channel from the side causing prolonged conditions of saturation and gleyed soils (gh horizons) next to the stream channel. Some water can however enter cracks and fissures in the relatively impermeable rock and feed deeper lying water bodies.

The vertical sequence of horizons of the upper slopes; orthic A (ot), yellow brown apedal B (ye) and red apedal B (re) (WRB - ferrilic), might be an indication of lateral movement close to the surface horizons (3). Near surface macropore flow is often observed in areas with topsoil horizons rich in organic matter. Organic matter increases the macroporosity of soils and favours the generation of preferential flow. The accumulation of clay in the on horizon in the midslopes of the south facing slope confirms this lateral flowpath (3). Clay is eluviated from the upperslopes and transported laterally until it accumulates at the break of slope in the on horizons.

The importance of studying hydrological processes at hillslope scale is emphasized by the soil distribution pattern of the Two Streams catchment. In both hillslopes the subsoil colour sequence is red then yellow and grey in the valley bottom. Although most of the soils show no indications of lateral flow, the colour sequence suggests that there is significant lateral flow at hillslope scale. 


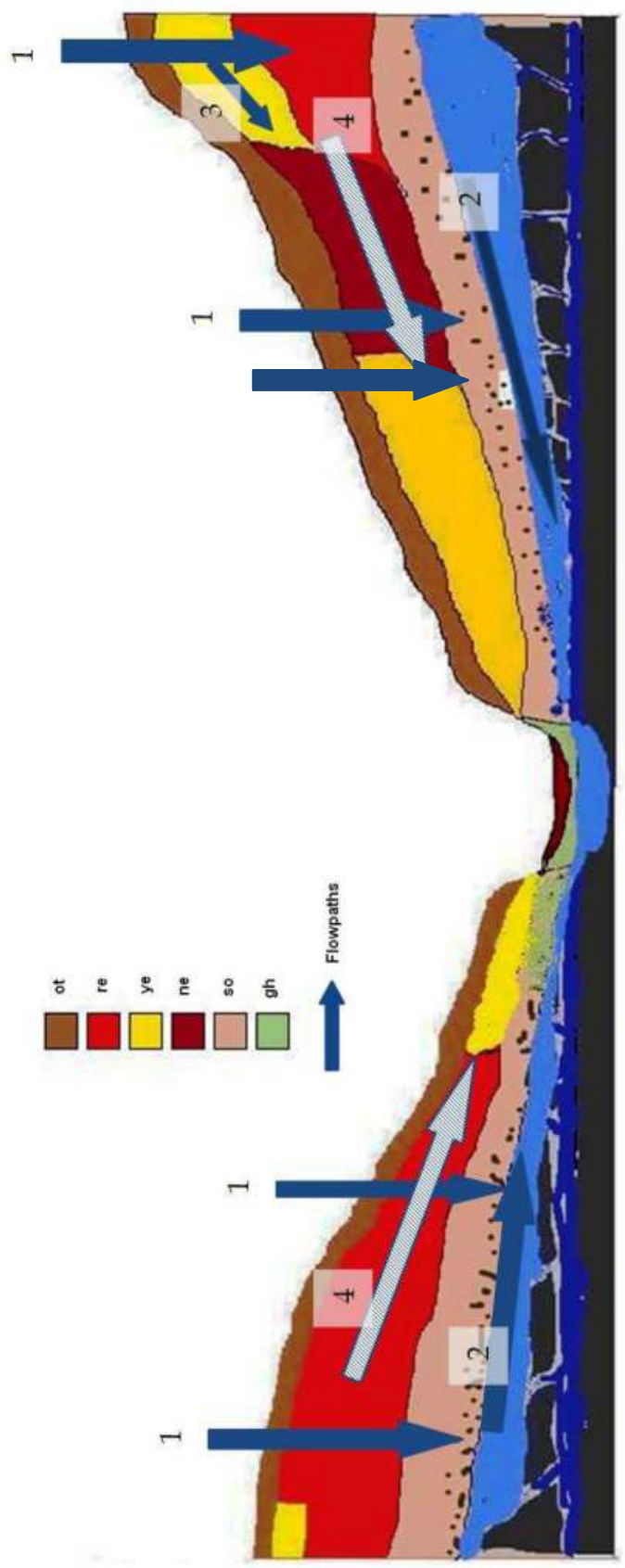

Fig. 9. Conceptual model of hillslope hydrological behaviour in the Two Streams catchment (Le Roux et al., 2010) 


\section{Hydropedological applications in hydrological modelling}

\subsection{Introduction}

The hydrological response of catchments is dependent on the combined responses of the individual hillslopes within the catchment (Sivapalan, 2003). The hillslope is generally accepted as a fundamental landscape unit (Lin et al., 2006; Weiler \& McDonnell, 2004), and is the smallest scale for holistically understanding and simulating hydrological processes (Tromp van Meerveld \& Weiler, 2008). It is therefore not surprising that the hillslope forms the basic building block for a number of hydrological models.

The current dominant paradigm in hydrological modelling involves using an a priori set of small scale theories and process descriptions (e.g. Darcy and Richard's equations) and splitting the catchment into small enough uniform elements for these theories to work. The models arising from this paradigm emphasize the explicit mapping of landscape heterogeneities and process complexities which, according to McDonnell et al. (2007), are an impossible task in even the most intensively studied catchments. Consequently the models based on current theories rely strongly on calibration, mimicking past data, to account and compensate for the lack of understanding of the actual hydrological processes and heterogeneities in the landscape (McDonnell et al., 2007; Sivapalan 2003). This results in models that 'work' but for the wrong process reasons (Weiler et al., 2004) and models highly over parameterized with many combinations of the parameters resulting in the same final result. This leads to a large degree of modelling uncertainty and models unsuitable for predictions in ungauged basins (Beven, 2001 and McDonnell et al., 2007).

Another current weakness in hydrological modelling is the gap between experimentalists and modellers. For example, an experimentalist may propose a conceptual model of hydrological behaviour of a system based on observations, measurements and experience. The appropriateness of the concept can only be verified when a numerical model is built (Bredehoeft, 2005). Unfortunately modellers usually do not incorporate the experimentalist's knowledge into the model structure (McDonnel et al., 2007; Sivapalan 2003; Tromp-van Meerveld et al., 2008; Weiler et al., 2004). When they do, simulations are followed by calibration exercises, which, together with limited understanding of the complex processed involved lead to further confusion by "correcting" with imperfect data (Dunn et al., 2008). On the other hand experimentalists have focussed on the documentation of the unconventional behaviour of new hillslopes instead of the systematic examination of first order controls of hillslope hydrological behaviour, without intercomparisons to obtain common process behaviours (Weiler et al., 2004). The transference or extrapolation value of these hillslope studies is therefore minimal. Some researchers argue that every hillslope is therefore unique (Beven, 2001). This is possibly true to a certain extent, since after hundreds of experiments we appear to be no further towards a common conceptualization of hillslope hydrology, and experimentalists have not yet expressed what the minimal set of measurements are to characterize even a single hillslope (McDonnel et al., 2007; Tromp-van Meerveld et al., 2008; Weiler et al., 2004)! There is a great need for closer collaboration between experimentalist and modellers (Siebert and McDonnell, 2002). Neither the conceptual model of the experimentalist nor the numerical model of the modeller should be considered untouchable, but the common focus should be to, through iteration of concepts and numbers, represent the physical process numerically.

In this section a modelling exercise using hydropedological data for model parameterization and configuration is described. Although model outputs are presented, the main aim of the 
exercise was to evaluate the capability of a mechanistic model to utilize hydropedological inputs. Simulations were run over two rainfall seasons in the Weatherley research catchment and simulated streamflow and soil moisture contents were compared to measured values. Only one model run was conducted i.e. there were no calibrations with measured data to improve model outputs.

\subsection{The hydrological model and model setup \\ 5.2.1 ACRU-Int}

$A C R U$ is an agrohydrological, daily time step, multi-layered soil water budgeting model. The standard version, ACRU2000, comprises of two soil layers (A and B- horizon) and a deep groundwater layer. Soil inputs include; the thickness of soil horizons, water contents at the start of simulation (SMAINI and SMBINI), Permanent Wilting Point (PWP), Drained Upper Limit (DUL), saturation (Po), Plant Available Water (PAW), drainage rates (ABRESP and BFRESP) and the erodibility of the soil (K-factor). Except for the latter all inputs are required for both soil horizons (Schulze, 2007).

PWP, DUL and Po are largely determined by the soil texture, organic matter and the bulk density. Typical values for these parameters are proposed in chapter 5 of the ACRU user manual (Smithers and Schulze, 2004) for different textural classes and clay distribution models, i.e. change in clay content with depth. The clay distribution models and typical texture classes were assigned to the 501 soil series of the binomial soil classification of South African soils (MacVicar et al., 1977). Relatively accurate PWP, DUL and Po values are therefore easily accessible for all South African soils. The PAW is the difference between DUL and PWP and is used to calculate the initial water content, expressed as a percentage of PAW (Smithers al., 2004).

ACRU-Int is a revised version of the standard ACRU2000 model. In addition to the 2 soil layers (A\&B-horizons) an intermediate layer (saprolite) between the soil and deep groundwater levels was introduced (Lorentz et al., 2007). The intermediate layer has a mechanism whereby lateral release of water can be induced when certain threshold positive pressures at the saprolite/bedrock interface is achieved. The lateral releases from the intermediate zone can be routed to any layer of a downslope land segments. This is ideal for imitating flowpaths at hillslope scale.

The model allows redistribution of saturated water (RESP), i.e. between DUL and Po, from the $\mathrm{A}$ to the B-horizon (ABRESP) and from the B-horizon to the groundwater (BFRESP). The distribution is expressed as a fraction of the water above DUL draining vertically downwards from the respective horizons on a daily time step. In Schulze (1995) typical RESP values are presented for different textural classes. Low RESP values in a particular horizon will result in the buildup of water above DUL in the soil horizons above it favouring the generation of lateral flow in that horizon. Thus a low ABRESP value will favour lateral flow in the A horizon and a low BFRESP value will favour lateral flow in the B horizon. Reductions in RESP are therefore suggested based on the "Interflow Potential" (IP) of different soil series, high IP $=$ RESP $\times 0.3$ and moderate IP $=$ RESP $=0.6$ (Schulze, 1995). The influence of the redistribution fractions on the simulated soil water contents is illustrated in Fig. 10.

Water contents in one land segment were simulated with ACRU-Int for six years with actual climatic data from the Weatherley catchment (Fig. 10). Four different RESP fractions were used a) $\mathrm{ABRESP}=0.01 \& \mathrm{BFRESP}=0.01, b)$ ABRESP $=0.99 \& \mathrm{BFRESP}=0.99, c)$ ABRESP $=$ $0.99 \&$ BFRESP $=0.01$ and $d$ ) ABRESP $=0.01 \&$ BFRESP $=0.99$. Simulation $a$ and $b$ show similar trends with a buildup of water in the A-horizon, relatively low water contents in the 
B-horizon and a general decrease in the water content of the C-horizon due to very little vertical drainage from the A to lower horizons. In simulation $b$, water is allowed to drain freely to the B-horizon and then to the C-horizon, resulting in relatively low water contents in the A and B-horizons but accumulation in the C-horizon. Simulation $c$ show water freely draining from the A-horizon but due to the impeding C-horizon (BFRESP $=0.01$ ) buildup in the B-horizon, slowly reducing the water content in the C-horizon.

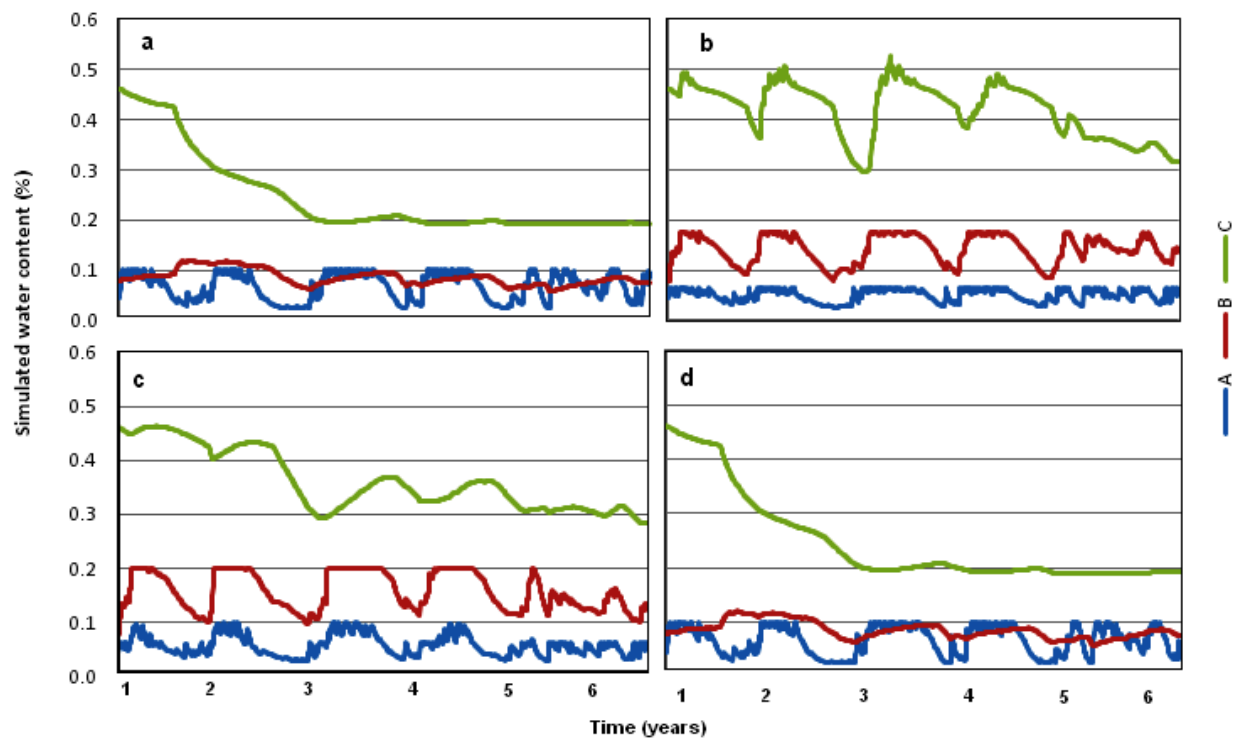

Fig. 10. Water contents (\%) for three horizons in the Weatherley catchment with different RESP values simulated over 6 years with ACRU-Int

It is clear from Fig. 10 that the RESP values play an integral part in the simulation of soil water contents and consequently on the outflow of different land segments. Exactly how these values were obtained is however not clear. For example; one would expect a direct relationship between the saturated hydraulic conductivity $\left(\mathrm{K}_{\mathrm{s}}\right)$ and the RESP value. In Schulze (1995) however a siltyloam horizon with $\mathrm{K}_{\mathrm{s}}$ of $6.8 \mathrm{~mm} \cdot \mathrm{h}^{-1}$ has a RESP of 0.45 whereas a sandyclayloam with $\mathrm{K}_{\mathrm{s}}$ of $4.3 \mathrm{~mm} \cdot \mathrm{h}^{-1}$ has a RESP of 0.50 , similarly, a loam horizon and a sandyslayloam soil were attributed the same RESP value $(0.50)$ although the $K_{s}$ of the former is triple that of the latter. The heterogeneous horizonation in terms of the textural distribution is the driving force for lateral flow generation in soils and is the basis for assigning "Interflow Potential" values to different soil series. If texture differences are the main reason for differences in RESP values is it not spurious to reduce the RESP value based on the IP? The volume of water draining vertically in a profile is also related to the slope of the land. Steeper slopes generally favour more lateral flow, and less vertical distribution of saturated water. Also, soils with shallow horizons ought to distribute a greater percentage of water in a particular day compared to soils with deep horizons although the texture and hydraulic conductivities are similar.

Another important parameter in ACRU-Int, not considered a soil input but definitely influenced by the soil, is QFRESP. According to definition QFRESP is: Stormflow response 
fraction for the catchment/subcatchment, i.e. the fraction of the total stormflow (1.0) that will run off from the catchment/subcatchment on the same day as the rainfall event (Smithers et al., 2004). QFRESP is inversely correlated with catchment area and will increase with an increase in slope angle, area covered by impervious material, and rainfall intensity. Soils prone to topsoil crusting as well as very shallow or very wet soils should therefore give high QFRESP values. No physical based methods to obtain suitable QFRESP values are however proposed by the modellers, and thus the appropriateness of the values used depends on calibration.

$A C R U$ can also account for unsaturated flow of water (IUNSAT) and flow through cracks or fissures in swelling soils (ICRACK). The latter is divided into three classes based on the clay content. Both IUNSAT and ICRACK can be excluded from simulations.

\subsubsection{Model configuration}

For the purpose of the modelling exercise the Weatherley catchment was divided into 7 land segments, each one with distinct hydrological responses (Fig. 11). The division was made derived from several pedological, soil physical, hydrogeological, geophysical and geochemical studies, as well as in-field observations of visible hydrological processes in the selected catchment over the past few years (Lorentz. 2001; Lorentz et al., 2004; Lorentz et al., 2007; van Huysteen et al., 2005; van Tol et al., 2010b). Some soil and landscape attributes, obtained from representative soil profiles of the land segments are presented in Tables 1 and 2. Two representative hillslopes, with diverse hydrological behaviour, were identified based on the properties of the land segments, their sequence from the crest to the river, and the area covered by the individual segments. Conceptual 2-dimensional flow models were then developed and applied to construct flow routings for the two hillslopes (Le Roux et al., 2010). Hillslope 1 includes land segments $1-4$, and hillslope 2 includes land segments $5-7$

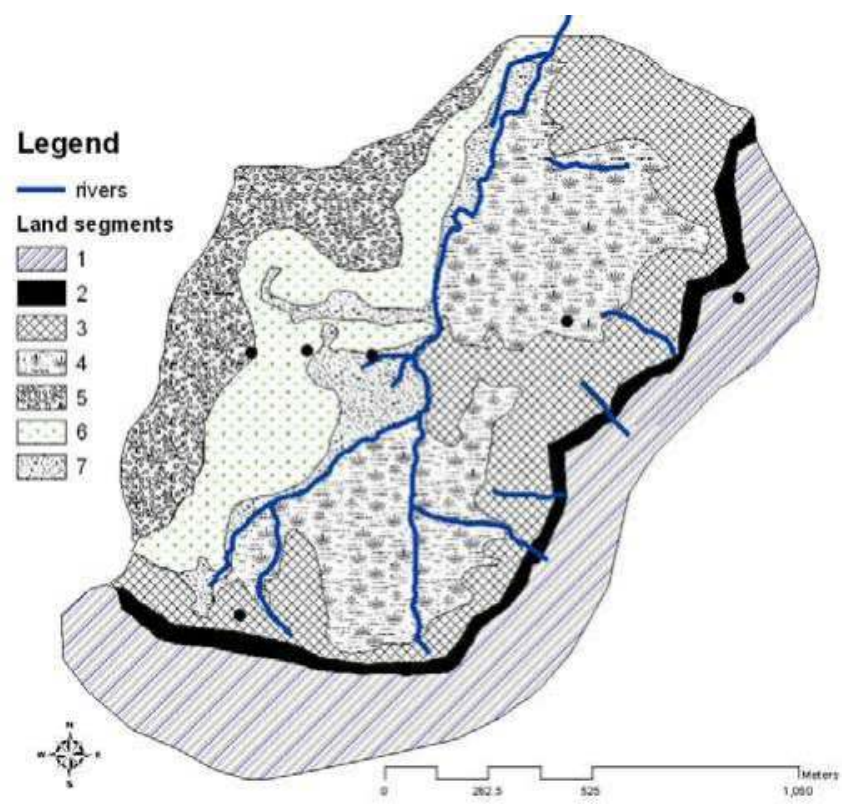

Fig. 11. Different land segments in the Weatherley catchment 
(Fig. 12). Land segments 4 and 7 represent the valley bottom or wetland area; they drain to a separate land segment (9) which represents the stream network. Since the deep groundwater levels are always below the stream channel and do not contribute to low flows, all the drainage out of the intermediate zone into the groundwater layer was routed to another land segment (8). Land segment 8 is therefore not linked to any streamflow generation process. The routing between land segments is presented in Fig. 12.

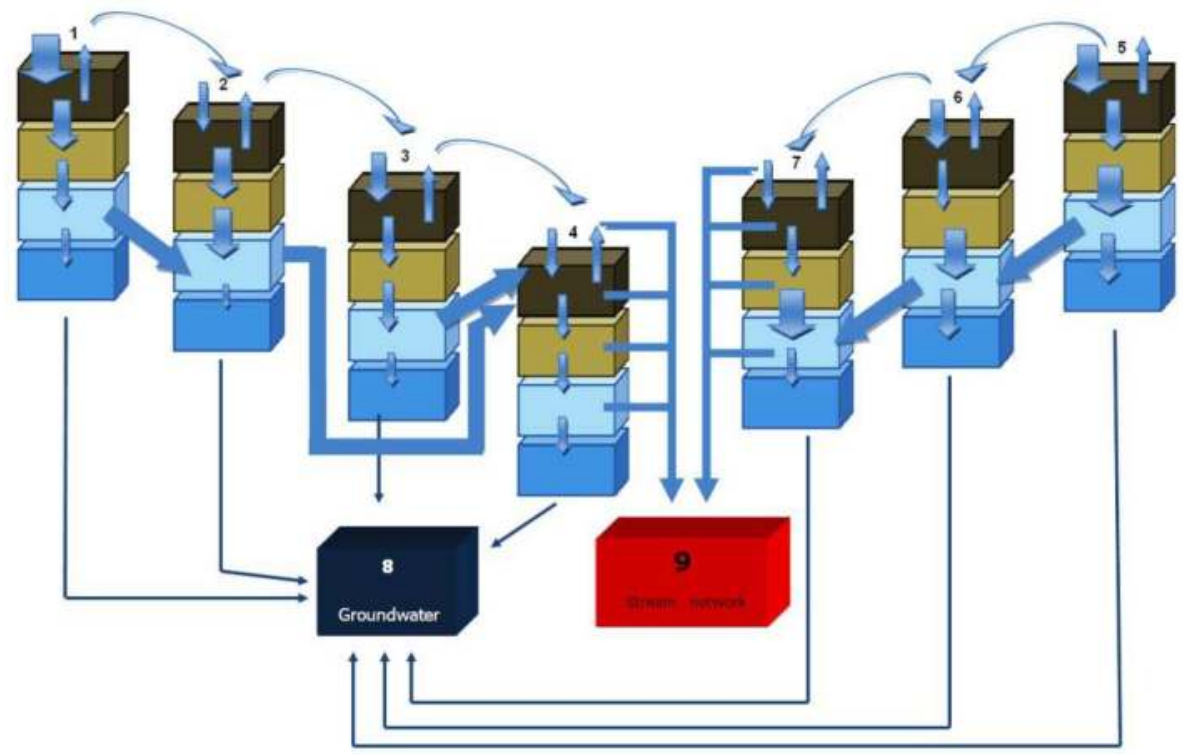

Fig. 12. Flow routing for the simulation, the magnitude of the arrows giving an indication of dominant flow directions in various land segments, the number of each one corresponding to the number in Fig. 11

\subsubsection{Model parameterization}

Imitating the dominant hydrological processes was one of the major aims of this simulation exercise. According to Sivapalan (2003), parameters without measured values require calibration with gauged data in order to reflect reality. This leads to uncertainty in predictions when dealing with unguaged basins. Parameter values, not directly available from soil profile descriptions, were therefore physically estimated based on the definition of the parameter and the (limited) understanding of the process influenced by the parameter. These calculations include:

- ABRESP, BFRESP and INTRESP: The difference between $K_{\mathrm{s}}$ of the top and lower horizon gives an indication of the vertical distribution from the former to the latter. $\mathrm{K}_{\mathrm{s}}$ values were calculated using ROSSETA (Schaap, 2000) for all the horizons of profiles representing the different land segments using texture class distributions and bulk densities $\left(D_{b}\right)$. The ratio of the $K_{s}$ of the lower horizon to the $K_{s}$ of its overlying horizon was used to estimate the particular RESP value. $\mathrm{K}_{\mathrm{s}}$ of the R-horizon were measured. Representative texture class, $D_{b}$ and estimated $K_{s}$ values are presented in Table 1 and resulting ABRESP, BFRESP and INTRESP values in Table 2. 


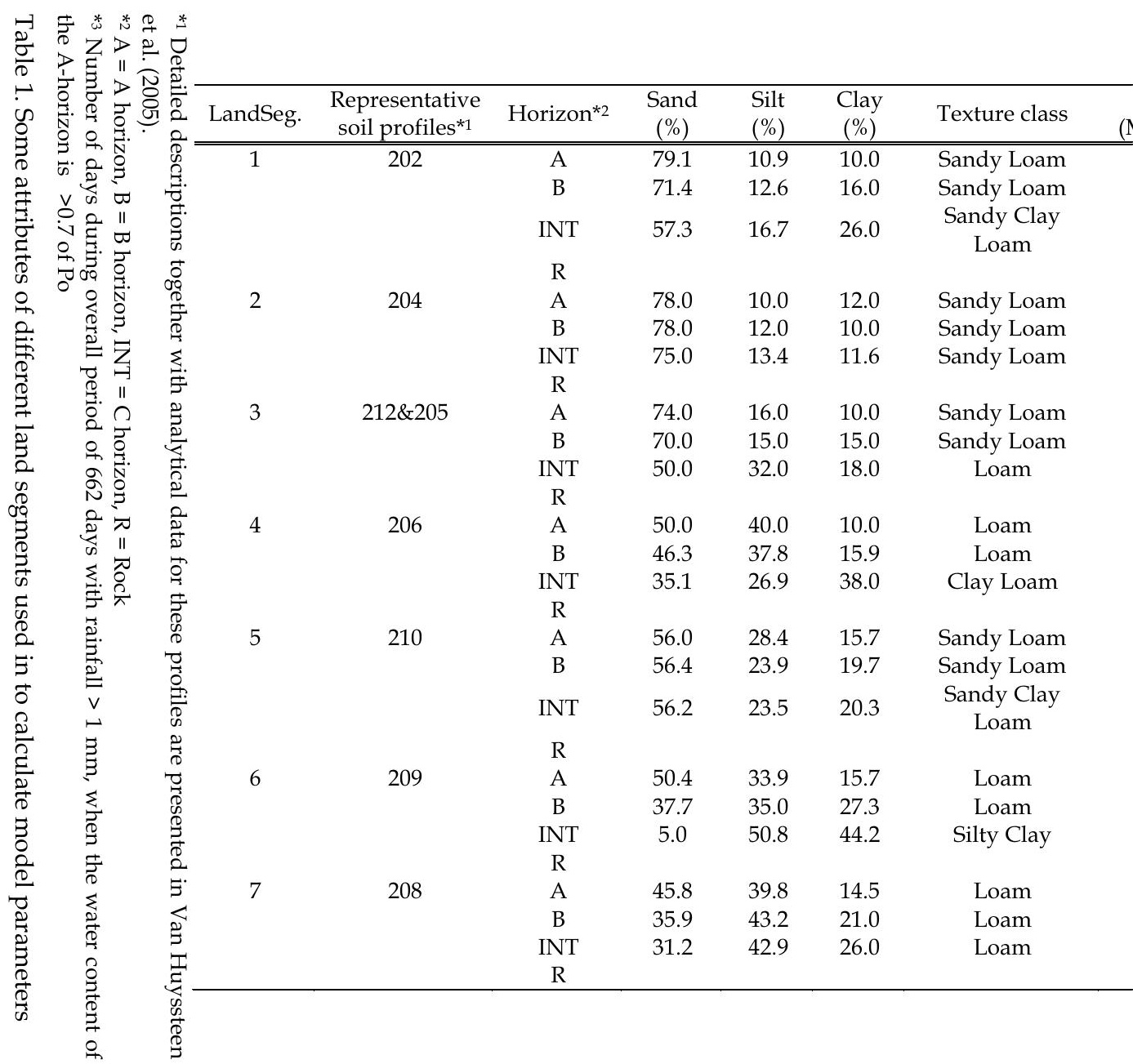




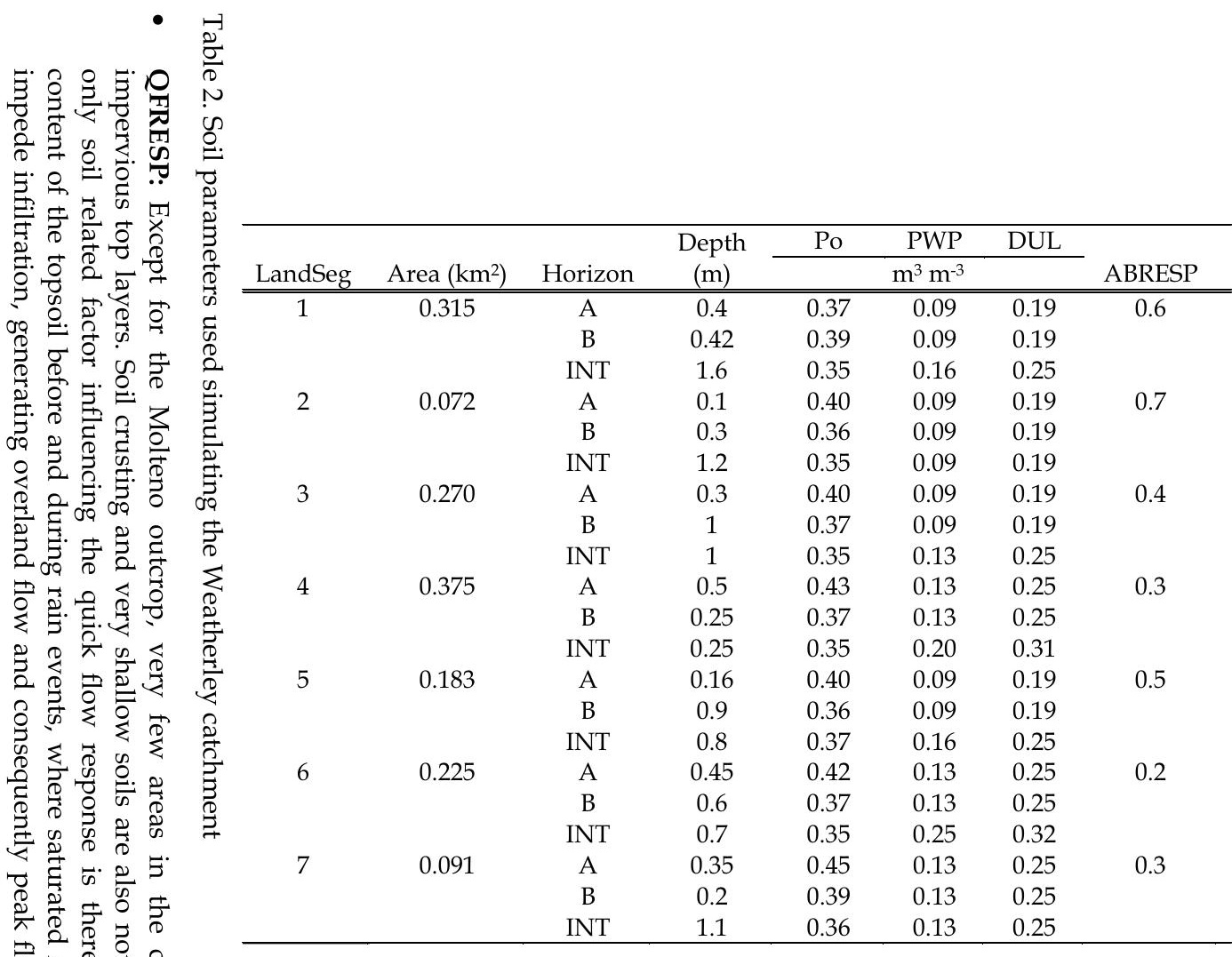


estimated daily soil water contents, based on weekly neutron probe measurements, over a 6 year period for 28 profiles in the Weatherley catchment. This was used to determine the number of days that A-horizons of the representative profiles were close to saturation $(>0.7$ of Po) on days with more than $1 \mathrm{~mm}$ of rain, during an overall number of 662 days in a 6 year period. The result is presented in Table 1 and resulting QFRESP values in Table 2. Approximately half of land segment 2 is covered by the impervious Molteno rock outcrop and was taken into account for calculation of QFRESP.

The thickness of A and B-horizons was obtained from Van Huysteen et al., 2005 for the profiles representing the different land segments. Where the lower depth of the profile was reached the B2 or C horizon was used as the depth of the intermediate zone, if not, an extra $0.5 \mathrm{~m}$ was added to the B2 or C horizon to acquire the intermediate zone depth. PWP, DUL and Po values were estimated based on typical texture class values proposed in Smithers et al., 2004.

The simulation period is from $1^{\text {st }}$ Jan 1998 till 31st August 2001. Simulated results are reported for two rain seasons, starting from the $1^{\text {st }}$ of September 1999 to allow the model to 'settle' and incorrect data regarding initial water contents to even out. Trees were planted on parts of the catchment in 2002 and 31st August 2001 was therefore selected as the end of simulation to avoid dissimilarity between vegetative covers.

Rainfall and, when possible, minimum and maximum temperature data were obtained from the BEEH (2003) database. Other climatic data was obtained from the quaternary catchment database. Streamflow was measured at a Crump weir at the catchment outlet and data regarding the streamflow obtained from BEEH (2003) database. Daily simulated soil water contents were compared to daily water contents calculated from weekly neutron water meter readings (Zere, 2005). Soil water contents are expressed as a fraction of porosity (Po).

\subsection{Modelling results}

\subsubsection{Streamflow}

Simulated and measured outflow from catchment for the simulation period is presented in Fig. 13. A R $R^{2}$ value of 0.64 was attained with a linear line deviating almost $100 \%$ from the $1: 1$ line. The divergence is towards measured flow, i.e. a greater volume of flow was measured than simulated. Figures 15 and 16 accentuate the cause of the deviation from the 1:1 line.

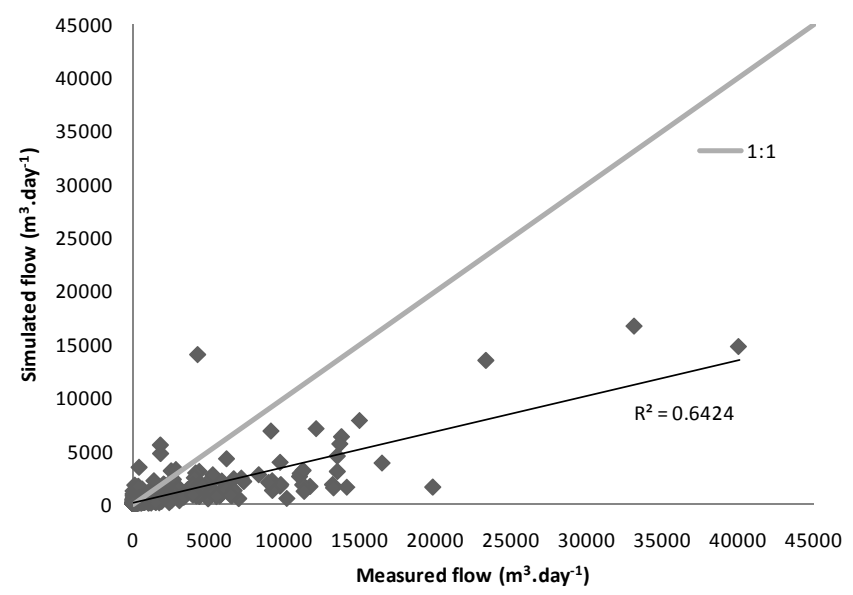

Fig. 13. Simulated vs. measured flow during the selected simulation period 


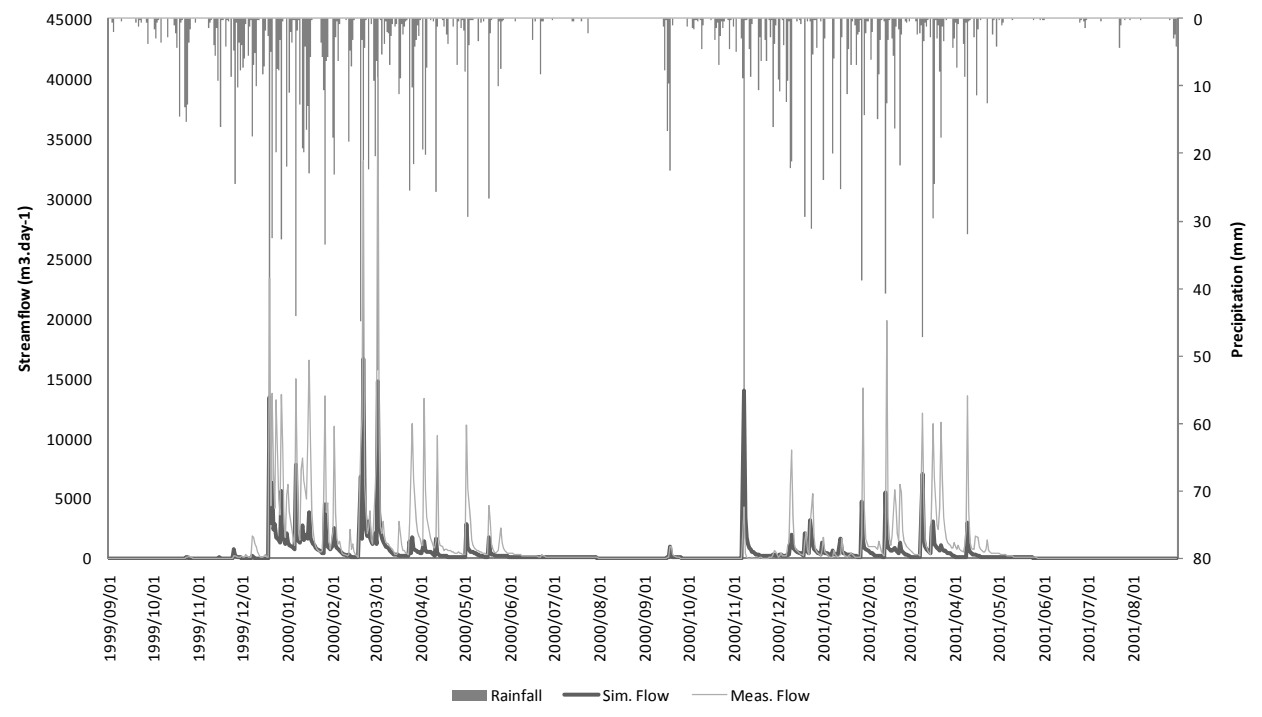

Fig. 14. Simulated vs. measured daily streamflow flow plotted against daily rainfall for the simulation period

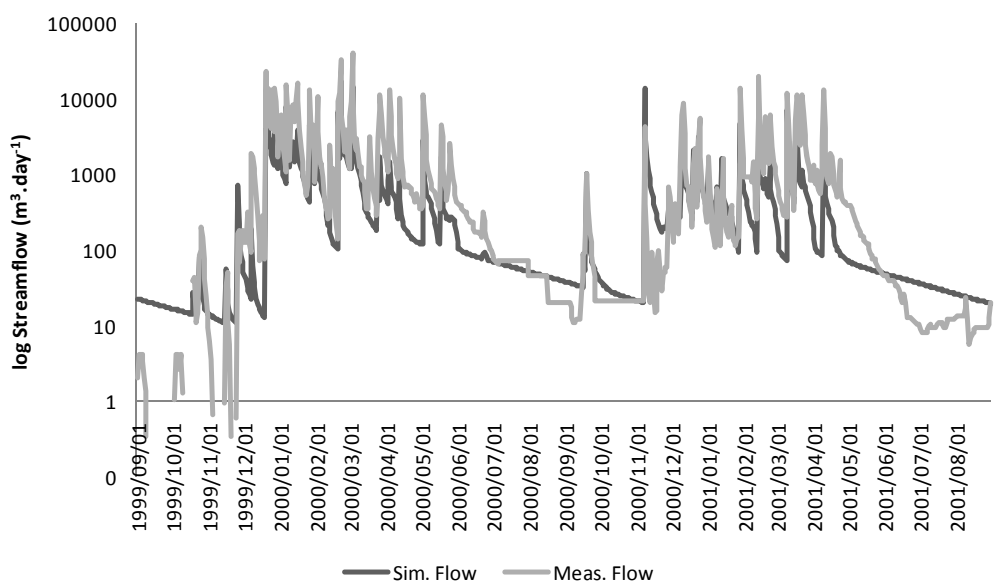

Fig. 15. Log of simulated vs. measured flow over the selected simulation period

Fig. 14 illustrates daily measured flow compared to simulated flow and also the influence of rainfall on flow volumes. It is clear from Fig. 14 that flows are overestimated especially towards the end of the rain seasons. Simulated low flows compared well with measured flows. Rain early in each season resulted in much smaller volumes of streamflow compared to similar size storms just before the end of the rain season. This over estimation of high flows and good representation of low flows is also emphasized in Fig. 15 where comparisons are plotted on a log scale. 
Fig. 15 shows high flows being overestimated by an order of magnitude in under some conditions. Low flows and streamflow recession are however simulated reasonable well in drier periods. The average daily difference between simulated and measured results over the simulation period is $854 \mathrm{~m}^{3}$ day $^{-1}$. This increases to $1194 \mathrm{~m}^{3}$ day-1 during the rainfall months (October to April) and decreases to $114 \mathrm{~m}^{3}$ day-1$^{-1}$ for months normally associated with little or no rainfall. For ten day periods after any recorded rainfall, the difference between simulated and measured streamflows is only $16 \mathrm{~m}^{3}$ day-1.

\subsubsection{Soil water contents}

The comparisons between simulated and measured soil water contents of land segment 1 are presented in Fig. 16. The figure is divided into four segments starting with daily rainfall data at the top then simulated vs. measured water contents of the A and B-horizon and then simulated vs. measured water contents of the intermediate zone or C-horizon at the bottom. The water contents are expressed as a fraction of the porosity for the different horizons.

Fig. 16 shows a very good correlation between measured and simulated water contents of the A-horizon. Measured water contents for this horizon is slightly higher for most of the simulation period but drainage is quicker than simulated at the end of the rain season. Measured water contents are far higher than those simulated for the B-horizon (Fig. 16). Seasonal variation is evident in the simulated water contents but not as profound in the measured values. Sharp increases and decreases are noted in measured values, but not in simulated water contents. Measured and simulated water contents of the C-horizon compared well, although the measured contents show less seasonal variation than those simulated (Fig. 16). The response of this horizon to rainfall at the beginning of the simulation period shows a lag time of about 2 months.

\subsection{Discussion}

Underestimation of quick flows can be attributed to low QFRESP values. The method used to estimate QFRESP awarded high values for the wetland regions i.e. land segments 4 and 7 . Van Tol (2010) showed that approximately $92 \%$ of the precipitation on the wetland will arrive at the catchment outlet on the same day. It was therefore surprising that QFRESP values of 0.92 and 0.82 for land segments 4 and 7 respectively were insufficient to generate comparable peak flows (Table 2). There are two possible explanations for this: some portions of land segments 3 and 5 form part of the wetland and should therefore be given higher QFRESP values; upslope land segments 1 and 5 make a larger contribution to daily flows than what their QFRESP values suggest. The latter is supported by findings of Lorentz et al. (2007), as well as our later trench and slotted pipe experiments which show a significant volume of water flowing laterally in the A-horizon of upslope land segments. This near 'surface macropore flow' can contribute approximately $16 \%$ of event water (Lorentz et al., 2007) and should be taken into consideration when assigning QFRESP values to land segments. The result for the A horizon of land segment 1 presented in Fig. 16 do not however support that suggestion. The reliable simulation of water content for this horizon indicates that the simulated amount of water infiltrating the profile is more or less in agreement with actual infiltration, and that the QFRESP value i.e. 0.002, for this land segment is satisfactory. One could argue that increasing QFRESP and lowering ABRESP would result in similar water contents in the A-horizon, as there would be less recharge of the B horizon and therefore a larger volume build-up in the A horizon. This will however deprive water from the already underestimated B-horizon and will alter the reasonably well 
simulated water balance of the intermediate zone (Fig. 16). Similarly one cannot simulate less surface water from the A-horizon of land segment 5 by assigning a higher QFRESP value, as water contents of this horizon are underestimated for the greatest part of the simulated period. Lowering the ABRESP would decrease the water content of the already underestimated B-horizon and changing the BFRESP will adversely adjust the relatively well simulated water contents of the intermediate zone.

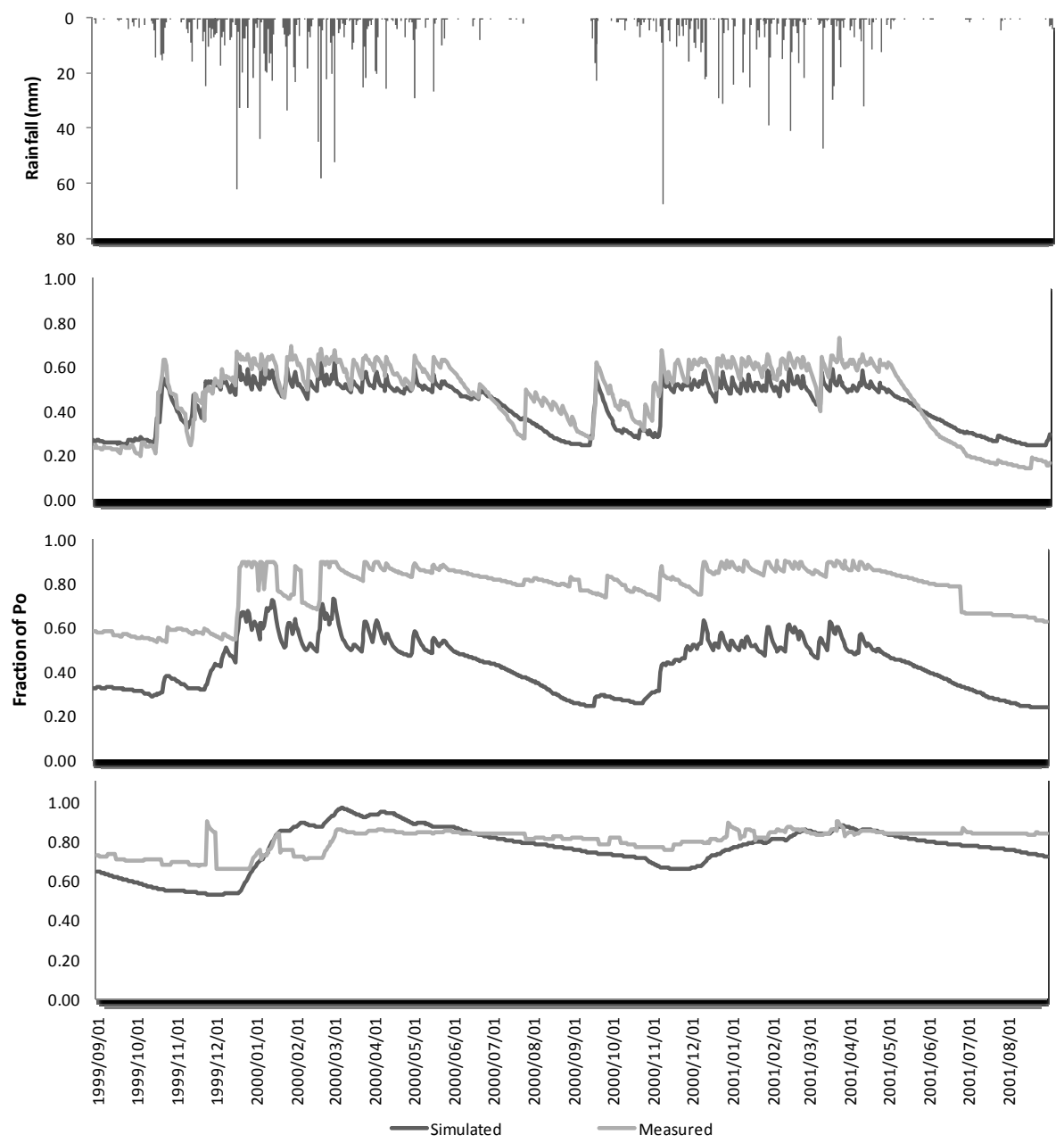

Fig. 16. Rainfall and simulated vs. measured water contents of A, B and C-horizons (top to bottom respectively) of land segment 1

In both land segments 1 and 5 the water contents of the C-horizon are simulated fairly well. Assigning higher QFRESP values to compensate for underestimation of peak flows and then lowering ABRESP, BFRESP and also INTRESP should probably result in comparatively 
water content simulations and might increase the accuracy of streamflow predictions. That would however be the antithesis of the aim of this study and will definitely not contribute to predictions in ungauged basins.

It is clear that a method for attaining accurate QFRESP values is needed. This method should encompass soil and landscape properties and should preferable be dynamic in nature, as one of the major driving forces for quick flow generation is the antecedent water content of the topsoil. The latter is in accord with the well known 'variable source area' concept. The influence of the antecedent water on streamflow is further emphasized in Fig. 13. In the 1999/2000 season the first significant increase in streamflow was recorded on the $8^{\text {th }}$ of December after $153 \mathrm{~mm}$ of precipitation had been recorded from the beginning of September. For the 2000/2001 season the first significant increase in streamflow was recorded on the $7^{\text {th }}$ of November following $110 \mathrm{~mm}$ of precipitation from the beginning of September. Before the $8^{\text {th }}$ December 2000 and the 7th of November, 'peak flows' were overestimated by the model as the storage capacity of the catchment had not yet been filled.

Simulated low flows correspond very well with measured flows (Fig. 14). Simulations in Le Roux et al. (2010) using ACRU2000 (in lumped and distributed mode) and ACRU-Int (using 1 and 3 land segments), could simulate high flows moderately well but was unsuccessful in simulating low flows. It is believed that the model configuration used in this study represents the actual processes generating base flow, i.e. drainage from the soil and not from groundwater, and it was therefore encouraging to observe the connection between simulated and measured outflows.

Water contents of the A-horizon were over estimated for the majority of the simulation period in land segments 2, 3, 4, 6 and 7. The reality is that the land segments represent an area, whereas the profiles with the measured data only represent a point in that area. This should be kept in mind. Lateral flow, such as near surface macropore flow, occurs in a downslope direction. When the representative profile is in the lower regions of the land segment, these lateral contributions might have accumulated in the horizons resulting in higher measured compared to simulated water contents. The same applies for the underestimation of water contents in the B-horizons of all land segments except for 3 . Routing of A and B-horizons to A, B and C horizons of different land segments might aid in solving this problem and ensure a better imitation of actual hydrological processes.

\section{Conclusions}

The grand challenge for predictions in ungauged basins (and for hydrological modeling as a whole) requires a holistic approach based on an improved understanding of the complex hydrological system and landscape heterogeneity. Soil acts as first order control in catchment hydrology through governing of water flowpaths and thereby influencing residence times and storage mechanisms. Water controls soil formation to such an extent that the soil carries signatures (morphological properties) of the hydrological processes involved in soil genesis. Based on this interactive relationship, soil scientists can make a valuable contribution to the improved understanding of the hydrological behaviour of the system.

The interactive relationship between soil and hydrology was demonstrated through conceptualizing the dominant hydrological response of soil profiles in the Weatherley catchment with six years of measured soil water contents. Results supported the interpretations and emphasized the different hydrological behaviour of different soils. This 
led to identification of three hydrological soil types namely recharge, interflow and responsive soil types, based on water movement and storage within these soils. The interpretation and conceptualization of soil distribution patterns of hillslopes in the Weatherley and Two Streams catchments reflected the actual hydrological behaviours of these hillslopes. Soil property distribution at hillslope scale proves to be a vehicle for identifying and studying first order controls of hillslope hydrological behaviour.

There is abundant evidence from international and local sources that soil information can improve efficiency of hydrological models. Because hydropedological studies are still in their infancy in South Africa (and in the world) huge gaps exist between the modelers (hydrologists) and experimentalists (soil scientists). Future studies should aim to close the gap by more interaction with all stakeholders. Only through interdisciplinary research can problems like pollution, land use change, floods and climate change be solved.

There is need to expand these hydropedological studies in order to improve qualitative and quantitative understanding, conceptualization and characterization of flowpaths, connectivity's, thresholds, non-linearity's and residence times at hillslope scale. This can only be achieved through intensive studies of soils in hillslopes over a wide range of climates and geologies.

\section{References}

Asano, Y., Uchida, T. \& Ohte, N., 2002. Residence times and flow paths of water in steep unchannelled catchments, Tanakami, Japan. Journal of Hydrology 261, pp. (173-192).

BEEH, 2003. Weatherley Database V1.0. School of Bio-resources Engineering and Environmental Hydrology, University of Natal, Pietermaritzburg.

Beven, K. J., 2001. On fire and rain (or predicting the effects of change). Hydrological processes 15, pp. $(1397$ - 1399).

Bockheim, J. G. \& Douglass, D. C., 2006. Origen and significance of calcium carbonate in soils of southwestern Patagonia. Geoderma 136, pp. (751 - 762).

Boorman, D. B., Hollis, J. M. \& Lilly, A., 1995. Hydrology of soil types: a hydrologically based classification of the soils of the United Kingdom. IH Report No.126. Institute of Hydrology, Oxfordshire, UK.

Clothier, B. E., Green, S. R. \& Deurer, M., 2008. Preferential flow and transport in soil: progress and prognosis. European Journal of Soil Science 59, pp. (2 - 13).

Driessen, P. \& Deckers, J., 2001. Lecture notes on the major soils of the world. http:/ / www.fao.org/DOCREP/003/Y1899E/y1899e09.htm. (Retrieved 26/05/2008).

Dunn, S. M., Freer, J., Weiler, M., Kirkby, M. J., Seibert, J., Quinn, P.F., Lischied, G., Tetzlaff, D. \& Soulsby, C., 2008. Conceptualization in catchment modelling: simply learning? Hydrological processes 22, pp. (2389 - 2393).

Fanning, D. S. \& Fanning M. C. B., 1989. Soil: Morphology, Genesis and Classification. Wiley \& Sons, New York. pp. (360-369).

Hillel, D., 1980. Fundamentals of soil physics. Academic Press, New York.

IUSS Working Group WRB. 2006. World reference base for soil resources 2006. 2nd edition. World Soil Resources Reports No. 103. FAO, Rome.

Karvonen, T., Koivusalo, H., Jauhiainen, M., Palko, J. \& Weppling, K., 1999. A hydrological model for predicting runoff from different land use areas. Journal of Hydrology. 217, pp. (253-265). 
Kutílek, M. \& Nielson, D. R., 2007. Interdisciplinary of hydropedology. Geoderma, 138, pp. $(252-260)$.

Le Roux, P. A. L., 1996, Die aard, verspreiding en genese van geselekteerde redoksmorfe gronde in Suid Afrika. Ph. D. Thesis. University of the Orange Free State, Bloemfontein.

Le Roux, P. A. L., van Tol, J. J., Kuenene, B. T., Hensley, M., Lorentz, S. A., Everson, C. S., van Huyssteen, C. W., Kapangaziwirri, E. \& Riddell, E. S., 2010. Hydropedological interpretations of the soils of selected catchments with the aim of improving the efficiency of hydrological models. Report No. K5/1748. Water Research Commission, Pretoria, South Africa.

Lilly, A., Boorman, D.B. \& Hollis, J.M., 1998. The development of a hydrological classification of UK soils and the inherent scale changes. Nutrient Cycling in Agroecosystems 50, pp. (299 - 302).

Lin, H. S., 2003. Hydropedology: bridging disciplines, scale and data. Vadose Zone Journal, 2, pp. $(1-11)$.

Lin, H. S., Kogelman, W., Walker, C. \& Bruns, M. A., 2006. Soil moisture patterns in a forested catchment: A hydropedological perspective. Geoderma 131, pp. (345 - 368).

Lin, H. S., Bouma, J., Owens, P. \& Verpraskas, M., 2008. Hydropedology: Fundamental issues and practical applications. Catena 73, pp. $(151-152)$.

Lin, H. S., 2010. Earth's critical zone and hydropedology: concepts, characteristics and advances. Hydrol. Earth. Syst. Sci. 14, pp. $(25-45)$.

Lorentz, S. A., 2001. Hydrological systems modelling research programme: hydrological processes. Report No. 637/1/01. Water Research Commission, Pretoria.

Lorentz, S. A., Thorton-Dibb, S., Pretorius, C. \& Goba, P., 2004. Hydrological systems modelling research programme: hydrological processes. Report No. 1061 \& 1086/1/04. Water Research Commission, Pretoria.

Lorentz, S. A., Bursey, K., Idowu, O., Pretorius, C. \& Ngeleka, K., 2007 (a). Definition and upscaling of key hydrological processes for application in models. Report No. K5/1320. Water Research Commission, Pretoria.

MacVicar, C. N., De Villiers, D. E., Loxton, R. F., Verster, E., Lambrechts, J. J. N., Merryweather, R. F., Le Roux, J., Van Rooyen, T. H. \& Von Harmse, H. J., 1977. Soil Classification - a binomial system for South Africa. Dept. Agric. Tech. Serv. Pretoria.

McDonnell, J. J., Sivapalan, M., Vaché, K., Dunn, S., Grant, G., Haggerty, R., Hinz, C., Hooper, R., Kirchner, J., Roderick, M. L., Selker, J. \& Weiler, M., 2007. Moving beyond heterogeneity and process complexity: A new vision for watershed hydrology. Water Resources Research 43, pp. (1-6).

McGlynn, B. L., McDonnell, J. J. \& Brammer, D. D., 2002. A review of the evolving perceptual model of hillslope flowpaths at the Maimai catchments, New Zealand. Journal of Hydrology 257, pp. (1-26).

Mosley, M. P., 1982. Surface flow velocities through selected forest soils South Island, New Zealand. Journal of Hydrology 55, pp. (65-92).

Nahar, N., Govindaraju, R. S., Corradini, C. \& Morbidelli, R., 2004. Role of run-on for describing field-scale infiltration and overland flow over spatially variable soils. Journal of Hydrology. 286, pp. (36-51). 
Netterberg, F., 1978. Dating and correlation of calcretes and other pedocretes. Trans. Geol. Soc. S. Afr., 81, $379-391$.

Nieber, J. L., Bauters, T. W. J. Steenhuis, T. S. \& Parlange, J. Y., 2000 Numerical simulation of experimental gravity-driven unstable flow in water repellent sand. Journal of Hydrology, 231, 295-307Park, S. J., Mcsweeney, K. \& Lowery, B., 2001. Identification of the spatial distribution of soils using a process-based terrain characterization. Geoderma. 103, pp. (249-272).

Park, S. J. \& Van De Giesen, N., 2004. Soil-landscape delineation to define spatial sampling domains for hillslope hydrology. Journal of Hydrology. 295, pp. (28 - 46).

Schaap, M. G., 2000. ROSETTA version 1.2. U. S. Salinity Laboratory. ARS-USDA.

Schulze, R. E. 1995. Hydrology and agrohydrology: A text to accompany the ACRU 3.00 agrohydrological modelling system. Water Research Commission, Report No 63/2/84. WRC, Pretoria.

Schulze, R. E., 2007. Soils: Agrohydrological information needs, information sources and decision support. In Schulze, R.E (Ed). 2007. South African atlas of climatology and agrohydrology. Report No. 1489/1/06. Water Research Commission, Pretoria.

Seibert, J. \& McDonnell. J. J., 2002. On the dialog between experimentalist and modeller in catchment hydrology: Use of soft data for multicriteria model calibration. Water Resour. Res. 38 (11), 1241, doi:10.1029/2001WR000978.

Shankar, N. \& Achyuthan, H., 2007. Genesis of calcic and petrocalcic horizons from Coimbatore, Tamil Nadu: Micromorphology and geochemical studies. Quaternary International 175, pp. (140 - 154).

Siddle, R. C., Noguchi, S., Tsuboyama, Y. \& Laursen, K., 2001. A conceptual model of preferential flow systems in forested hillslopes: evidence of seld-organization. Hydrol. Process. 15, pp. (1675-1692).

Sivapalan, M. 2003a. Prediction in ungauged basins: a grand challenge for theoretical hydrology. Hydrol. Process., 17, pp. (3163 - 3170).

Sivapalan, M., Takeuchi, K., Franks, S.W., Gupta, V.K., Karambiri, H., Lakshmi, V., Liang, X., McDonnell, J.J., Mendiono, E. M., O'Connell, P.E., Oki, T., Pomeroy, J.W., Schertzer, D., Uhlenbrook, S., \& Zehe, E., 2003. IAHS decade on prediction in ungauged basins (PUB), 2003 - 2012: Shaping an exciting future for the hydrological sciences. Hydrol. Sci. J. 48 (6) pp. $(857$ - 880).

Smithers, J. \& Schulze, R. E., 2004. ACRU Agrohydrological modelling system: user manual v4.00. School of Boiresources Engineering and Enviromental Hydrology, University of Natal, Pietermaritzburg.

Soulsby, C. \& Tetzlaff, D., 2008. Towards simple approaches for mean residence time estimation in ungauged basins using tracers and soil distributions. Journal of Hydrology 363, pp. $(60-74)$.

Soil Classification Working Group, 1991. Soil Classification - A taxonomic system for South Africa. Mem, agric. Nat. Resour. S. Afr. No. 15. Dept. Agric. Dev., Pretoria.

Soil Survey Staff, 1992. Keys to Soil Taxonomy, $5^{\text {th }}$ edn. Pocahontas Press Inc., Blacksburg, Virginia.

Ticehurst, J. L., Cresswell, H. P., McKenzie, N. J. \& Clover, M. R., 2007. Interpreting soil and topographic properties to conceptualise hillslope hydrology. Geoderma 137, pp. $(279-292)$. 
Tromp-van Meerveld, I. \& Weiler, M., 2008. Hillslope dynamics modelled with increasing complexity. Journal of Hydrology 361, pp. $(24-40)$.

Uchida, T., McDonnell, J. J. \& Asano, Y., 2006. Functional intercomparison of hillslope and small catchments by examining water source, flowpath and mean residence time. Journal of Hysrology 327, pp. (627-642).

Uhlenbrook, S., Wenninger, J. \& Lorentz, S., 2005. What happens after the catchment caught storm? Hydrological processes at the small, semi-arid Weatherley catchment, South-Africa. Advances in Geosciences 2, pp. (237 - 241).

Van Breedeman, N. \& Brinkman, R., 1976. Chemical equilibria and soil formation. In G. H. Bolt \& M. G. M. Bruggrnwert (eds.). Soil chemistry. A. Basic elements. Elsevier, Amsterdam.

Van Huyssteen, C. W. \& Ellis, F., 1997. The relationship between subsoil colour and degree of wetness in a suite of soils in the Grabouw district, Western Cape I. Characterization of colour-defined horizons. S. Afr. J. Plant Soil, 14, pp. (149 - 153).

Van Huyssteen, C. W., Hensley, M., Le Roux, P. A. L., Zere, T. B. \& Du Preez, C. C., 2005. The relationship between soil water regime and soil profile morphology in the Weatherley atchment, an afforestation area in the Eastern Cape. Report no. 1317/1/05. Water Research Commission, Pretoria.

Van Huyssteen, C. W., 2008. A review of the advances in hydropedology for application in South Africa. S. Afr. J. Plant Soil, 25, pp. (245-254).

Van Tol, J. J., Le Roux, P. A. L., Hensley, M. \& Lorentz, S. A., 2010. Soil as indicator of hillslope hydrological behaviour in the Weatherley Catchment, Eastern Cape, South Africa. Water SA. 36, pp. (513 - 520).

Van Tol, J. J., Le Roux, P. A. L. \& Hensley, M., 2010a. Soil properties as indicators of hillslope hydrology in the Bedford catchments. S. Afr. J. Plant E Soil 27, pp. $(242-251)$.

Verpraskas, M. J. \& Bouma, J., 1976. Model experiments on mottle formation simulating field conditions. Geoderma 15, pp. (217-230).

Webster, R. 2000. Is soil variation random? Geoderma 97, pp. (149 - 163).

Weiler, M. \& McDonnell, J., 2004. Virtual experiments: a new approach for improving process conceptualization in hillslope hydrology. Journal of Hydrology 285, pp. (3 18).

Wenninger, J., Uhlenbrook, S., Lorentz, S. \& Leidbungut, C., 2008. Identification of runoff generation processes using combined hydrometric, tracer and geophysical methods in a headwater catchment in South Africa. Hydrological Sciences-Journal-des Sciences Hydrologiques 53, pp. $(65-80)$.

Zere, T. B., 2005. The hydropedology of selected soils in the Weatherley catchment in the Eastern Cape of South Africa. Ph.D. Dissertation. University of the Free State, Bloemfontein. 


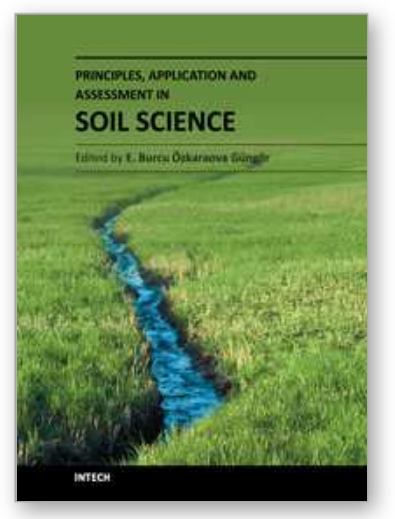

\author{
Principles, Application and Assessment in Soil Science \\ Edited by Dr. Burcu E. Ozkaraova Gungor
}

ISBN 978-953-307-740-6

Hard cover, 394 pages

Publisher InTech

Published online 22, December, 2011

Published in print edition December, 2011

Our dependence on soil, and our curiosity about it, is leading to the investigation of changes within soil processes. Furthermore, the diversity and dynamics of soil are enabling new discoveries and insights, which help us to understand the variations in soil processes. Consequently, this permits us to take the necessary measures for soil protection, thus promoting soil health. This book aims to provide an up-to-date account of the current state of knowledge in recent practices and assessments in soil science. Moreover, it presents a comprehensive evaluation of the effect of residue/waste application on soil properties and, further, on the mechanism of plant adaptation and plant growth. Interesting examples of simulation using various models dealing with carbon sequestration, ecosystem respiration, and soil landscape, etc. are demonstrated. The book also includes chapters on the analysis of areal data and geostatistics using different assessment methods. More recent developments in analytical techniques used to obtain answers to the various physical mechanisms, chemical, and biological processes in soil are also present.

\title{
How to reference
}

In order to correctly reference this scholarly work, feel free to copy and paste the following:

Johan van Tol, Pieter Le Roux and Malcolm Hensley (2011). Soil Indicators of Hillslope Hydrology, Principles, Application and Assessment in Soil Science, Dr. Burcu E. Ozkaraova Gungor (Ed.), ISBN: 978-953-307-740-6, InTech, Available from: http://www.intechopen.com/books/principles-application-and-assessment-in-soilscience/soil-indicators-of-hillslope-hydrology

\section{INTECH}

open science | open minds

\section{InTech Europe}

University Campus STeP Ri

Slavka Krautzeka 83/A

51000 Rijeka, Croatia

Phone: +385 (51) 770447

Fax: +385 (51) 686166

www.intechopen.com

\section{InTech China}

Unit 405, Office Block, Hotel Equatorial Shanghai

No.65, Yan An Road (West), Shanghai, 200040, China

中国上海市延安西路 65 号上海国际贵都大饭店办公楼 405 单元

Phone: +86-21-62489820

Fax: $+86-21-62489821$ 
(C) 2011 The Author(s). Licensee IntechOpen. This is an open access article distributed under the terms of the Creative Commons Attribution 3.0 License, which permits unrestricted use, distribution, and reproduction in any medium, provided the original work is properly cited. 